\title{
Axonal Organelles as Molecular Platforms for Axon Growth and Regeneration after Injury
}

\author{
Veselina Petrova $^{1, *,+}+\mathbb{D}$, Bart Nieuwenhuis ${ }^{1,2} \mathbb{D}$, James W. Fawcett ${ }^{1,3}$ and Richard Eva $1, * \mathbb{D}$ \\ 1 John van Geest Centre for Brain Repair, Department of Clinical Neurosciences, University of Cambridge, \\ Cambridge CB2 0PY, UK; bn246@cam.ac.uk (B.N.); jf108@cam.ac.uk (J.W.F.) \\ 2 Cambridge Institute for Medical Research, University of Cambridge, Cambridge CB2 OXY, UK \\ 3 Centre for Reconstructive Neuroscience, Institute of Experimental Medicine CAS, \\ 14220 Prague, Czech Republic \\ * Correspondence: veselina.petrova@childrens.harvard.edu (V.P.); re263@cam.ac.uk (R.E.) \\ + Current Address: F.M. Kirby Neurobiology Center at Boston Children's Hospital and Harvard Medical \\ School, Centre for Life Sciences, Boston, MA 02115, USA.
}

\begin{abstract}
Investigating the molecular mechanisms governing developmental axon growth has been a useful approach for identifying new strategies for boosting axon regeneration after injury, with the goal of treating debilitating conditions such as spinal cord injury and vision loss. The picture emerging is that various axonal organelles are important centers for organizing the molecular mechanisms and machinery required for growth cone development and axon extension, and these have recently been targeted to stimulate robust regeneration in the injured adult central nervous system (CNS). This review summarizes recent literature highlighting a central role for organelles such as recycling endosomes, the endoplasmic reticulum, mitochondria, lysosomes, autophagosomes and the proteasome in developmental axon growth, and describes how these organelles can be targeted to promote axon regeneration after injury to the adult CNS. This review also examines the connections between these organelles in developing and regenerating axons, and finally discusses the molecular mechanisms within the axon that are required for successful axon growth.
\end{abstract}

B.; Fawcett, J.W.; Eva, R. Axonal

Organelles as Molecular Platforms for Axon Growth and Regeneration after Injury. Int. J. Mol. Sci. 2021, 22, 1798. https://doi.org/10.3390/ijms 22041798

Academic Editors: Lies De Groef and Lieve Moons

Received: 19 January 2021

Accepted: 8 February 2021

Published: 11 February 2021

Publisher's Note: MDPI stays neutral with regard to jurisdictional claims in published maps and institutional affiliations.

\section{Introduction}

Neurons of the peripheral and central nervous systems (PNS and CNS) represent a population of highly polarized cells, with axonal terminals usually located long distances away from the cell bodies. This unique morphology is crucial for proper neuronal function but also calls for intricate regulation of the processes governing axon growth and regeneration after injury.

During early development, neuronal processes undergo rapid growth with one process being specified as the axon [1-4]. The axon grows from its tip, the growth cone, and extends long distances through the extracellular environment. The growth cone is a highly dynamic structure which guides axons to their correct target by sensing, integrating and responding to signals from chemoattractive and chemorepellent cues [5]. In some human neurons, the axon could extend up to $1 \mathrm{~m}$ in length. The intricate process of axon growth requires enormous amounts of lipid synthesis, endosomal trafficking and correct positioning of materials and machinery at the plasma membrane in order to drive the axon forwards [6]. Furthermore, tight regulation of cytoskeletal dynamics and integrated intracellular signaling are key for successful axon growth, target identification and synapse formation [7].

Unlike PNS and embryonic CNS neurons, adult CNS neurons have very limited regenerative capacity and, therefore, re-grow poorly after injury. The mechanisms required for axonal extension after injury in many aspects mimic the processes that occur during developmental axon growth; however, the regenerative growth process is further complicated by 
the primary requirement for growth cone redevelopment. Recent studies have shown that stimulating developmental growth programs in the adult is one way of restoring axonal growth and function ([8] and summarized in $[9,10])$; however, there are a number of issues that need to be addressed in adult CNS neurons. For example, as neurons mature and form synapses, synaptic maintenance trumps growth and, as a consequence, the cell adjusts the availability and localization of the axon growth machinery to fit these newly found needs (reviewed in [11]). In addition, axonal injury can occur at long distances away from the cell body and, therefore, successful regeneration requires active axonal transport as well as local regulation of protein and lipids [12]. The extracellular environment after injury also differs for mature CNS neurons compared to the time of developmental CNS growth and to injured PNS neurons, with numerous inhibitory factors impeding growth after injury [13].

One requirement for the initiation of successful regrowth programs in the PNS after injury is the resealing of the plasma membrane and the formation of a new growth cone. These processes are highly dependent on calcium influx [14,15]. Calcium affects numerous intracellular signaling processes which communicate to the cell body to mount a regenerative response through the expression of regeneration-associated genes (RAGs), cytoskeletal remodeling or axonal transport [16,17]. A number of key intracellular signaling pathways have so far been identified that contribute to the regulation of axon regeneration including the PTEN/PI3K, the JAK/STAT, the ERK/MAPK and the RhoA/ROCK pathway [18-23]. However, targeting individual signaling pathways is insufficient to elicit optimal regeneration in the adult CNS and highlights the need for further approaches to enable the robust, long-range regeneration needed for functional recovery after injury.

Recent advances in microscopy and live-imaging techniques have highlighted that intracellular organelles are important signaling platforms and sources of the materials required for axon growth and regeneration. This review summarizes the evidence for intracellular organelles as sites of convergence for many growth and regeneration-associated pathways, discusses the numerous potential roles that inter-organelle connections might play during axon growth and regeneration, and debates how individual organelles or multi-organellar complexes could be targeted to stimulate axon growth. We review the current literature on the involvement of the endoplasmic reticulum (ER), mitochondria, the endo-lysosomal system and the proteasome during axon growth and regeneration. We also summarize the intricate interactions between different organelles and their significance in axon health and disease.

\section{Endoplasmic Reticulum}

\subsection{Structure and Function}

The endoplasmic reticulum (ER) is a membranous organelle that spans across the entire intracellular space and has essential physiological functions such as the synthesis and recycling of lipids, the maintenance of calcium homeostasis, metabolite processing as well as the synthesis and redistribution of secretory or membrane-associated proteins. The ER is composed of two distinct interconnected structures-ER tubules and flattened ER sheets. The latter could, in some cases represent a densely packaged network of tubules [24-26]. This structure supports a highly dynamic model where the ER can rapidly change its structure and distribution to meet any changing cellular demands and to modulate its interactions with various other organelles throughout the cell, making it a perfect candidate for a role in axon growth and regeneration.

In the cell body, most ER is studded with ribosomes (referred to as rough ER) which reflects its essential role in protein translation. The ER throughout the axon constitutes a continuous ribosome-free membranous structure of smooth ER tubules, which run in parallel to the axonal plasma membrane $[27,28]$. In some cases, an individual tubule has been found to span across the entire length of very thin axonal processes while at the same time maintaining its connection with ER in the rest of the cell [29-31]. This interconnectedness between differently shaped ER structures is essential for axon integrity and function [32] and is achieved by the function of ER-shaping proteins [33,34]. Mutations in ER-shaping 
proteins result in human neurological disease, highlighting their importance for proper axonal function [35]. For example, several mutations in hairpin-loop containing ER-shaping proteins such as reticulons, REEPs and atlastins have been described as causative of autosomal dominant hereditary spastic paraplegia (HSP), a condition where distal axons progressively degenerate resulting in severe motor and sensory symptoms [36,37]. Recent studies utilizing Drosophila models have shown that mutations in the reticulon and REEP families of ER-shaping proteins do indeed result in ER fragmentation and network disruption with physiological consequences in the distal axon, demonstrating that ER shaping and remodeling have direct effects on axon structure, function and maintenance [38-40].

The studies above indicate that a continuous, intact ER is required throughout the axon, and that disruption of axonal ER leads to degeneration. ER integrity could also have important implications in axon regeneration-rebuilding the structure and function of axonal ER after injury might be just as important as rebuilding the structure of the axon itself, perhaps even being an essential prerequisite before growth cone redevelopment. Examining the function and anatomy of the ER during developmental axon growth can help to understand how it might participate in successful axon regeneration.

\subsection{ER Shaping and Distribution in Axon Growth and Regeneration}

Many interactions are involved in shaping the ER and determining its distribution. Studies manipulating ER-related proteins have highlighted that the ER is an important organelle for developmental axon growth. In neurons, the tubular shape of the ER along the axon has been suggested to be favorable for the trafficking and function of other organelles and cellular components during rapid growth, therefore ER-shaping proteins are also desirable in those axon compartments [41]. ER-shaping proteins have indeed been found to be enriched throughout the axon and in the growth cone of developing [42-45] and regenerating axons [46,47]. For example, reticulons and atlastins are distributed throughout axons and dendrites of developing hippocampal neurons in culture [42] and at the growth cone of cultured cortical neurons where their depletion reduces axon growth in early development [48,49]. In addition, REEP1 colocalizes with atlastin and spastin in the growth cone, axonal varicosities and in the axon shaft of cortical neurons in culture [44]. In fact, knockdown of REEP1 or overexpression of an HSP-associated mutant form of REEP1 leads to impaired neurite outgrowth and results in axon degeneration in mouse primary cortical neurons [45]. Another study found enrichment of REEP5 and reticulon 4 proteins at the axonal growth cone of neurons overexpressing an active version of an ER-associated adaptor protein called protrudin, and this was associated with increased neurite outgrowth [43]. In addition, the reduction of protrudin's interaction with ERassociated proteins such as VAP-A has been shown to reduce axon growth in culture [50]. The ER has also been found to accumulate at both the proximal and distal part of newly growing neuronal-like processes in PC12 cells during a rapid state of growth, initiated by a directed dragging force with the use of nanoparticles [51]. The distribution and structural organization of ER tubules along the axon was also shown to be closely linked to microtubule stability and vice versa; this interaction was found to be critical for the establishment of neuronal polarity and axon specification during early development of hippocampal neurons [42].

A recent study in Drosophila suggests that ER, cytoskeletal dynamics and localization at the growth cone could be essential requirements for successful axon regeneration. In this study, ER and spastin proteins accumulated at the tips of regenerating axons after axonal but not dendritic injury [46]. Mutant flies defective for atlastin or spastin did not show ER enrichment at the growth cone after injury, which was concordant with impaired axon regeneration [46]. Another study found that exogenous reticulon-1-GFP, a fluorescent marker of smooth ER, localized to the tips of regenerating axons, but again not dendrites, in a model of a simultaneous injury to all processes of mature sensory neurons in Drosophila [47]. Interestingly, both axons and dendrites re-grew after injury and no growth deficits were observed in comparison to each process regenerating alone. In 
mammalian studies of axon regeneration, overexpression of the ER resident and shaping protein protrudin resulted in increased amounts of ER tubules in the distal axon and at the growth cone, and this was accompanied by extensive axon regeneration in rat cortical neurons after laser axotomy in vitro and in mouse retinal ganglion cells (RGCs) after optic nerve crush in vivo [43]. The regenerative effect of protrudin overexpression was abolished when its localization within the ER or its interaction with the ER contact site proteins VAP-A/B were removed [43].

\subsection{ER in Lipid Synthesis and Trafficking during Axon Growth and Regeneration}

Lipids are the major building blocks of all membranes. In some developing neurons, the plasma membrane surface area can expand up to $20 \%$ per day, a process which requires tightly regulated mechanisms for lipid synthesis and trafficking [6]. The ER is a major site for axonal biosynthesis of lipids such as phosphatidylcholine, sphingomyelin, phosphatidylethanolamine as well as fatty acids and phosphoinositides [52,53]. In fact, nearly half of the axonal phosphatidylcholine is locally synthetized in the distal axon and this synthesis is required for axon growth [54,55]. In addition, most major lipid synthetizing enzymes reside within the ER and their activity is regulated by feedback signaling from target organelles to the ER which is important for proper growth during development [56,57]. The sterol regulatory element-biding proteins which are resident ER-proteins can feedback on their own synthesis and this is a common mechanism through which pro-growth mTOR signaling can influence the production of lipids in the ER [58-60]. There are two major pathways through which lipids are transported from the ER to the plasma membrane (PM) during rapid axonal growth-vesicle-dependent and vesicle-independent transport. Vesicular transport of lipids is discussed in more detail in the section below on protein synthesis and trafficking.

Non-vesicular transfer of lipids from the ER to the PM depends on lipid transfer proteins acting at contact sites between the ER and the PM [61-63]. This mode of lipid delivery allows for fast and efficient insertion of locally synthetized lipids into rapidly expanding membranes during axonal outgrowth in comparison to vesicle transport [64]. Recent studies suggest that one mechanism of bulk lipid transfer during axon growth is driven by a protein complex consisting of at least ER-localized SNARE protein Sec22b and a plasma membrane SNARE protein syntaxin1 (Stx1) at the growth cone to create a non-fusogenic bridge between the ER and the PM $[65,66]$. This lipid transfer and protein complex was recently shown to be regulated by extended synaptotagmin (E-Syt) which is an ER-resident lipid transfer protein. Overexpression of E-Syt in developing neurons dramatically enhances neurite outgrowth and neurite ramification by stabilizing the Sec22bStx1 interaction and providing contact sites for lipid insertion to drive new membrane expansion [67]. Importantly, this process depends on E-Syt being localized within the ER [67].

\subsection{ER in Protein Synthesis and Trafficking during Axon Growth and Regeneration}

A historical view of axon growth suggests that signaling proteins, growth receptors and other growth-promoting molecules are exclusively synthetized in the cell body in the rough ER and transported to the developing or regenerating axon via microtubulebased transport [68]. Indeed, whilst the majority of membrane proteins are most likely transported this way, recent studies have identified that proteins can also be synthetized locally, allowing for more efficient transport to the growth cone or the site of injury in response to the metabolic demands of the cell changing rapidly upon targeted axon growth or injury [30,69-76]. Despite the lack of conventional Golgi structures in neuronal processes, numerous elements of the protein synthesis pathway have been detected throughout axons and dendrites. Those include mRNAs, scattered ribosomes, polysomes and translational chaperones [77]. It is possible that many of these elements as well as other translational platforms such as endosomes and mitochondria associate with the ER in order to regulate this process $[30,72,75]$. Further studies are, however, needed in order to determine the exact 
role of axonal ER in local protein translation, particularly as axonal ER appears smooth and tubular, unlike the ribosome studded rough ER found in cell bodies. One way in which the ER has been shown to influence local axonal translation is through its regulation of calcium dynamics. For example, axonal injury can trigger calcium release from ER stores, which in turn could stimulate translation of axonal proteins aiding the regenerative response in PNS neurons $[78,79]$.

The trafficking and export of newly synthesized lipids and proteins in vesicular structures from the ER to the cell surface is a key mechanism that can influence axon growth and development $[55,80]$. ER-resident proteins can influence this process. For example, downregulation of atlastin in motor neurons in Drosophila results in altered secretory pathways and presynaptic protein distribution as well synaptic vesicle release, which ultimately resulted in behavioral deficits [81]. In addition, overexpression of reticulon-2 increased the delivery of glutamate transporter (EAAC1) from the endoplasmic reticulum to the plasma membrane [82]. Furthermore, VAP-A can be internally cleaved in the ER to initiate interaction with growth cone guidance receptors such as ephrins, Robo and Lar in order to influence axon guidance and pathfinding in the developing brain [83]. Interestingly, VAP-A was also shown to interact with tethering proteins such as Sec22 and Stx1 (which are mentioned earlier with regard to the non-vesicular trafficking of lipids) to stabilize PM-ER contact sites [67]. Another ER-resident protein, IER3IP1 was recently shown to regulate the ER ubiquitin-proteasome system (UPS) response and the secretory extracellular matrix molecules, with mutations leading to microcephaly and impaired developmental growth [84]. The trafficking and distribution to the cell surface of signaling receptors and ion channels such as NMDA [85], GABA [86] and AMPA receptors [87] were all shown to be ER-dependent.

\subsection{ER Calcium Buffering during Axon Growth and Regeneration}

Another major role for the ER during axon growth and regeneration is calcium buffering and regulated calcium release. The targeted elongation of axons during neuronal development in response to attraction cues is coupled to calcium release from the endoplasmic reticulum, which, in turn, aids the transport and exocytosis of VAMP2-positive vesicles on the side of the growth cone that has elevated calcium [88,89]. Another study demonstrated that Myosin Va can act as a sensor of ER-derived calcium to drive the release of membrane vesicles, which it normally tethers to two major ER channels-the ryanodine receptor type 3 (RyR3) and the 1,4,5-triphosphate (IP3) receptor (IP3R) [90]. This process was shown to be instrumental for attractive growth cone turning and for proper development of the chick spinal cord.

ER calcium buffering is an important step to allow for developmental growth and axon regeneration. For example, ER calcium-sensor STIM1 (stromal interaction molecule 1), localized with MT-plus-end binding proteins EB1/EB3 in growth cones upon BDNF exposure in developing zebrafish motor neurons [91]. STIM1 in turn promoted active ER remodeling, calcium signaling and growth cone steering during developmental axon guidance [91]. In addition, STIM1 and E-syts are actively involved in the formation of ER-PM contact sites [67], replenishment of ER calcium and the clustering of diverse proteins at the PM which has major implications for growth and regeneration [92,93]. In injury, ERregulated backpropagating calcium wave is required for the regenerative response in DRG neurons [94]. In addition, peripheral nerve injury in mouse DRG spot cultures accelerated ER calcium release, activated the unfolded protein response (UPR) at the injury site and aided new growth cones formation [95]. UPR activation after a sciatic nerve crush also promoted axon regeneration in DRG axons [96]. The role of ER-resident stress transducers such as IRE1 (Inositol-requiring enzyme 1) and CHOP (C/EBP-homologous protein) have also been implicated in motor neuron response after spinal cord injury [97] and in RGCs response after optic nerve injury [98]. The role of ER stress and the UPR response after injury and neurodegenerative disease have been extensively reviewed elsewhere $[99,100]$. 
In addition to ER's involvement in the regulation of growth, the ER could also act as a molecular platform for neurotransmission dynamics and proper brain function. Axonal ER calcium content as detected by STIM1, was previously shown to control neurotransmitter release at CNS axon terminals [101]. In addition, VAP-A interactions with secernin-1 (SCRN1) at the ER membrane was recently shown to not only be important for ER continuity but also for proper synaptic vesicle release and calcium homeostasis [102]. Furthermore, disruption in axonal autophagy was shown to result in increased tubular ER in axons leading to the dysregulation of calcium stores and aberrant synaptic activity [103].

Taken together, the endoplasmic reticulum appears to be a dynamic structure supporting numerous processes important for axon growth and regeneration such as lipid and protein synthesis as well as calcium homeostasis while at the same time acting as a platform for a variety of proteins important for signaling and response to injury.

\section{Mitochondria}

\subsection{Structure and Function}

Mitochondria are double-membrane organelles which were termed "the powerhouse of the cell" due to their role in ATP (adenosine triphosphate) production. However, mitochondria are also important for calcium buffering, redox homeostasis, apoptosis and cell death signaling [104-106]. The proper localization and functioning of mitochondria are important to meet the high energy demands of developing neurons and to support neuronal processes such as axon growth and neurotransmission. Recent advances in imaging have allowed for the visualization of mitochondria in vitro and in intact organisms such as mice and zebrafish [26,31,107-111]. Similar to other organelles, mitochondrial transport into the axon is mostly microtubule-based and relies on motor proteins such as kinesin and dynein as well as mitochondria-specific adaptor proteins such as Milton and Miro [112-116]. Importantly, these live-imaging studies showed that axonal transport of mitochondria is highly dynamic but also developmentally down-regulated in the CNS. In developing neurons, mitochondria are highly mobile, move bidirectionally and preferentially localize to the active growth cone [116-118]. In mature neurons, mitochondria move more slowly, exhibit elongated morphology and the majority of mitochondria are anchored in stationary positions along the axon $[107,110,118-120]$. In addition, mitochondria can be regulated by proteins such as PTEN, BDNF, mTOR, NGF, NOGO, semaphorins and CSPGs, which are all well-known molecules involved in signaling during neurite growth, axon regeneration and maintenance of synapses [121,122].

\subsection{Mitochondrial Fission and Fusion in Axon Growth and Regeneration}

Regulation of mitochondrial size by the processes of mitochondrial fusion and fission is an important determinant of developmental axon growth. Deletion of key fusion and fission proteins, such as MFN1, MFN2 and Opa1, leads to developmental deficits such as impaired axon growth and is lethal [123,124]. Increased mitochondrial fusion and decreased fission by DRP-1 (dynamin-like protein) downregulation was shown to suppress neurite outgrowth in RGCs, to decrease growth rate and to prevent growth cone turning on inhibitory substrates [121]. In the same study, mitochondrial size dynamics were shown to be developmentally down-regulated in RGCs, an event which coincides with the reduction in intrinsic axon growth and regeneration capacity [121]. Similarly, downregulation of mitochondrial fission factor (MFF) results in elongated mitochondria with altered calcium buffering capacity and this decreased neurotransmission and reduced terminal axon branching in cortical pyramidal neurons [125]. This study pinpoints the importance of maintaining small axonal mitochondria during neurotransmitter release and axon development. In addition, shorter and more mobile mitochondria were observed in regenerating motor axons after nerve injury and in retinal neurons after an optic nerve crush suggesting the importance of early mitochondrial fission after axonal injury [126]. Indeed, ablating mitochondrial fission resulted in elongated mitochondria, which also impaired mitochondrial functions and caused neuronal cell death [126]. Contradictory 
to the findings above, knockdown of mitochondrial pro-fission protein MTP18 increased mitochondrial size but also promoted axonal outgrowth in RGCs cultured on inhibitory substrates [122]. This approach had however no effect on axon regeneration or RGC survival after optic nerve crush in vivo [122]. Taken together, these results indicate that the optimal balance between mitochondrial fusion and fission might be cell type-specific, injury-dependent and cell compartment-driven but nonetheless, underline the importance of mitochondrial size and in its involvement in axon growth.

Mitochondrial biogenesis, energy production and transport into the axon are crucial mechanisms supporting axon growth. A hallmark study found that depletion of mitochondria prevented axon specification and polarization [127]. In cultured cortical neurons, overexpression of PGC- $1 \alpha$, a regulator of mitochondrial biogenesis and energy production, resulted in elongated axon and dendrites, while inhibition of glycolysis reduced oxidative phosphorylation or knockdown of PGC-1 $\alpha$ all inhibited neurite outgrowth [128]. Another study found that overexpression of PGC-1 increased mitochondrial density, improved its redox state and delayed Wallerian degeneration in a neurodegenerative model of zebrafish [111]. Axonal mitochondrial transport has a key role in the process of developmental axon growth. Deletion of motor adaptor Trak1 resulted in inhibited axon outgrowth and branching in cultured hippocampal neurons [129]. Deacetylation of adaptor protein Miro1 by HDAC6, a histone deacetylase, decreased mitochondrial transport and this was in line with reduced axonal growth of adult DRG neurons on growth-repulsive substrates [130].

\subsection{Mitochondrial Transport in Axon Growth and Regeneration}

In addition to their participation in developmental processes, mitochondria have been implicated as key players in axon regeneration and degeneration. Axonal injury results in mitochondrial depolarization and oxidative stress, processes which are associated with neurodegeneration and cell death [111,131]. Therefore, there is a need for functioning mitochondrial transport not only to remove unhealthy mitochondria but also to supply functioning ones for repair [118,132]. After axonal injury, key regenerative processes such as for membrane resealing, growth cone formation and axon extension require energy. Due to the limited capacity of intracellular ATP for long-range transport across the cell, efficient mitochondrial trafficking and the local production of ATP near the site of injury are key to successful regeneration [120]. Previous studies have shown that there is increased trafficking of mitochondria in injured but regenerating axons in vivo after peripheral nerve injury $[109,110]$ whereas dramatically reduced anterograde flux of mitochondria after injury was associated with poor regeneration and degeneration of the distal axon [110]. There is a possibility that the developmental decline in axonal transport of mitochondria in mature cells of the CNS could partly explain the regenerative failure seen in many adult models of axonal injury.

Studies into mitochondrial positioning and axon regeneration have identified a number of key regulatory molecules, including Armcx1 and syntaphilin. Armcx1 was identified after comparative gene expression profiling of non-regenerative and highly regenerative RGCs [133]. Overexpression of Armcx1, a mitochondria resident protein, resulted in increased mobility of mitochondria, which in turn promoted neurite outgrowth and survival not only in cultured embryonic cortical neurons but also in adult RGCs after optic nerve crush [133]. Interestingly, when Armcx1 is knocked out in a highly regenerative genetic model, both axon regeneration and cell survival are inhibited [133]. In a different study, mitochondria were found to be less mobile with maturation which was attributed to increased expression of mitochondrial anchor protein — syntaphilin and correlated with reduced regenerative capacity [118]. Knockout of syntaphilin in DRG neurons resulted in increased influx of mitochondria into the axon and increased axon regeneration both in vitro after axotomy and in vivo after sciatic nerve crush [118]. Interestingly, syntaphilin knockout did not result in developmental changes in axon growth. Syntaphilin knockouts have been used since to show increased corticospinal tract axon regeneration through a spinal cord 
lesion, improved regrowth of monoaminergic axons, increased sprouting and functional recovery in three different models of CNS injury [134]. Administering creatine-an energy facilitator-further exaggerated this effect, suggesting that improving mitochondrial transport and restoring cellular energetics is sufficient to promote regrowth and functional recovery in the injured CNS.

Mitochondrial transport as a regulator of regeneration has also been studied in C. elegans. In vivo laser axotomy of single axons showed a two-fold increase in the amount of mitochondria in the axon after injury where axons with low mitochondria density did not regenerate and axons with high mitochondria density showed robust regenerative response [112]. The regenerative response was dependent on mitochondrial transport in the axon as its blockade by Miro-1 RNAi prevented mitochondrial accumulation and regeneration whereas overexpression of Miro resulted in mitochondrial delivery to the axon and improved regeneration [112]. This injury-induced response was regulated by activation of DLK-1 (dual leucine zipper kinase 1) - a conserved axon regeneration kinase. Additionally, C. elegans in which the respiratory chain was defective also failed to regenerate implicating the importance of energy production for growth [112]. Indeed, elements of the electron transport chain were found to be essential for the regrowth of mechanosensory axons in C. elegans after laser axotomy; although, in this paradigm, mitochondria did not increase at the growing tip and defective fusion/fission genes did not alter regeneration [135]. In addition, C. elegans mutants lacking ric-7-a gene essential for mitochondrial localization - failed to transport mitochondria into the distal axon, which resulted in rapid axon degeneration after injury [136]. This effect could be completely reversed when mitochondria are supplied to the axon.

\subsection{Mitochondrial Calcium Dynamics in Axon Growth and Regeneration}

As discussed above in relation to the ER, transient influx of calcium after injury is an important factor for axon regeneration. Axonal mitochondrial calcium levels are regulated by MCU-1-a mitochondrial calcium transporter. In C. elegans, a deletion of translational repressor-CAR1 resulted in increased levels of MCU-1 which, in turn, resulted in a more sustained influx of calcium in axonal mitochondria and enhanced axon growth after injury [137]. In addition, both Miro and syntaphilin possess calcium-binding domains, which could result in regulation of axonal transport of mitochondria by surrounding calcium levels $[138,139]$. These studies underline the importance of mitochondrial calcium dynamics after injury for the processes of growth and regeneration.

\subsection{Mitochondria as Molecular Platforms for Axon Growth and Regeneration}

Additionally, mitochondria can also act as molecular platforms where various proteins can anchor and signal to influence the processes of growth and regeneration. Several kinases have been implicated in regulating mitochondrial function and dynamics. For example, the LKB1-NUAK1 pathway is involved in mitochondrial anchoring and immobilization in axons, which is a process essential for terminal axonal branching [140]. Activation of AMPK - a master regulator of cellular dynamics and ATP production during growth results in increased influx of mitochondria into the axon and induces axon branching in regions of high mitochondrial availability [141]. STAT3 is a transcription factor previously described as a promoter of axon growth and regeneration in the CNS [142]. In addition to its transcriptional activity, its localization within mitochondria was recently shown to improve their ATP production properties and support axon growth after optic nerve crush and spinal cord injury [143]. This effect was regulated by MEK kinase and further potentiated by PTEN deletion. NMNAT, an NAD+ synthetizing enzyme is another molecule functioning within mitochondria that support proper axonal function. For example, upregulation of NMNAT suppresses degeneration in adult Drosophila by alleviating injury-induced mitochondrial loss [144]. In fact, targeting NMNAT to mitochondria is fully sufficient to mimic the effects of Wlds mutation which was found to drastically delay Wallerian degeneration in both mice $[145,146]$ and Drosophila models after injury [146]. 
These effects were attributed to improved calcium buffering properties of mitochondria after injury and increased mitochondrial motility into axons.

In summary, mitochondria are organelles with diverse cellular functions that are essential for developmental axon growth and regeneration after injury and that could act as molecular platforms for intracellular signaling governing these processes.

\section{Endosomes}

\subsection{Structure and Function}

The endocytic pathway regulates the internalization of membrane and membraneassociated proteins into endosomes and their trafficking to and from the plasma membrane. These components are either recycled, transported to their target location within the cell, or sorted towards degeneration via late endosomes and the lysosome. Hence, endosomes can be targeted to different parts of the cell and the endocytic pathway can, therefore, exert a strong control over the localization of specific cellular machinery. The endocytic pathway also influences axon growth and regeneration by controlling cellular events such as intracellular signaling, membrane recycling, protein sorting and degradation [12,63,147-150]. The transport and function of endosomes is controlled by small GTPases such as the Rab, ARF and ARL families [151], which cycle between GDP- and GTP-bound states as a result of being regulated by a variety of activating or inhibiting factors. Specific GTPases mark and regulate specific endosomal populations. For example, early endosomes can be marked by Rab5, late endosomes by Rab7 and recycling endosomes by Rab4 or Rab11 [152-154]. Here, we summarize the role of key Rabs in axon growth and regeneration and some of the mechanisms through which they can govern these processes.

\subsection{Endosomal Regulation by Rab11 in Axon Growth and Regeneration}

Perhaps the most well-studied Rab during axon growth and regeneration is Rab11. Optogenetic targeting of different cytoskeletal motors to Rab11-positive recycling endosomes revealed that the addition of dynein motors resulted in removal of endosomes from the growth cone and reduced axon growth. In contrast, loading of kinesin onto these endosomes stimulated their transport towards growth cones and this dramatically improved axon growth in primary hippocampal neurons [155]. Overexpression of Rab11 or its effector-Rab-coupling protein-resulted in increased anterograde trafficking of growth-related integrin receptors to the cell-surface of adult DRG neurons [156] and in differentiated PC12 cells [157]. Rab11-positive endosomes colocalize with TC10, another GTPase involved in endosome recycling and vesicular fusion, in growth cones and undergo plasma membrane insertion via the exocyst complex [158]. The anterograde transport of Rab11-positive endosomes and the plasma membrane insertion potentiated axon growth in vitro [156-158]. Rab11-dependent endosomal transport was shown to be inhibited by the kinase LMTK1 in mouse cortical neurons where downregulation of LMTK1 had dramatic effects in aiding Rab11 trafficking to the growth cone and stimulated both axonal and dendritic growth and branching [159-161]. Rab11-positive endosome are preferentially localized in the somatodendritic compartment of mature CNS neurons in culture [162], and overexpression of Rab11 in vitro leads to increased anterograde transport of recycling endosomes in the axon and improved regeneration after laser axotomy in vitro [162].

Rab11 regulates recycling endosomes through a close interaction with one member of the ARF family of small GTPases, ARF6. Rab11 and ARF6 form a complex with the transport adaptor JIP3/4, the activation state of ARF6 determining whether the complex will associate with kinesin for anterograde transport or dynein for retrograde travel [163]. ARF6 has also been identified as a regulator or axon regeneration. Inactivation of ARF6 resulted in increased integrin-containing endosomal trafficking to the plasma membrane and aided integrin-mediated neurite outgrowth in DRG neurons [164]. In matured CNS neurons, integrin and Rab11 trafficking into the axon is prevented by EFA6, an ARF6 activator which localizes to the axon initial segment [165]. Knockdown of EFA6 in cortical 
neurons permits the transport of Rab11 endosomes containing growth receptors to the growth cone and enhances not only initial axon growth but axon regeneration as well [166].

Rab11 has also been targeted to enhance regeneration in vivo. Viral delivery of either protrudin (an ER adaptor protein) or p110 delta (a natively hyper-active catalytic subunit of phosphoinositide 3-kinase) enhanced regeneration in the optic nerve, and were accompanied by enhanced transport of Rab11 into the distal part of the axon $[20,43]$. Protrudin has previously been shown to assist the movement Rab11-positive endosomes to the tips of PC12 cell neurites and can also stimulate the formation of cellular protrusions in non-neuronal cells [157]. It was recently demonstrated that overexpression of wildtype or activated protrudin leads to increased axonal transport of Rab11 in cortical neurons in vitro, as well as robust, long-range regeneration after an optic nerve crush injury [43]. In addition, overexpression of p110 delta in cortical neurons leads to increased anterograde transport of Rab11, partly through a down-regulation of ARF6 activity, but also by signaling via mTOR and CRMP2. This approach enabled regeneration after an optic nerve crush injury, identifying p110 delta overexpression as an alternative approach to boosting axon regeneration through the PI3K/PTEN pathway and manipulation of regenerative transport of Rab11-positive endosomes [20].

\subsection{Endosome Regulation by Other Rabs in Axon Growth and Regeneration}

A number of other Rab family GTPases have been shown to influence endosome function in plasma membrane expansion and receptor insertion during developmental axon growth [150,167-169]. Rab5 and Rab4 were both shown to co-localize with endosomes at Xenopus RGC growth cones where they are locally recruited to assist membrane recycling [170]. Mutations that disrupt Rab4 or Rab5 function resulted in decreased axon growth both in vitro and in vivo, but did not alter pathfinding, indicating a role for early endosomes in developmental axon extension [170]. These results were recently confirmed by another study which found that expression of mutant forms of Rab5 impaired axon growth in cultured Xenopus RGCs [30]. Mutations in Rab7, which are also associated with human neuropathy, were shown to cause developmental defects in axon growth, branching and pathfinding of sensory neurons in zebrafish [171]. Rab33a colocalizes with and regulates the transport of synaptophysin-positive vesicles destined for membrane insertion during neurite outgrowth [172]. Downregulation of Rab33a resulted in a decreased number of vesicles at the growth cone and reduced axon growth in rat hippocampal neurons [172]. Rab35, another GTPase involved with cargo loading onto recycling endosomes was also shown to play an important role in axon outgrowth in rat primary neurons [173]. Rab35 is degraded by a p53-related protein kinase (PRPK) through the UPS which negatively impacts axon growth. This degradative process is regulated by MAP1B - a microtubule-associated protein which blocks PRPK action and allows for Rab35-assisted axon extension [173]. This study highlighted the interplay between endosomal trafficking, the cytoskeleton and protein degradation in the process of axon growth. Furthermore, the anterograde transport and vesicle fusion of post-Golgi Rab10-positive vesicles carrying various growth receptors were shown to be essential for neurite outgrowth during development in vitro and in vivo [174-176].

In regeneration, macrophage-derived NOX2 complexes were shown to be incorporated into Rab7-positive endosomes of DRG neurons after injury, where they influence PI3K signaling to stimulate neurite outgrowth and axon regeneration after sciatic nerve lesion [177]. A genome-wide screen of factors limiting axon regeneration in mouse cortical neurons in vitro, identified that Rab27 negatively impacted axon growth and regeneration. Rab27 is involved in synaptic vesicle regulation and its silencing resulted in increased axon regeneration in C. elegans and increased axon regeneration after optic nerve crush and spinal cord injury in mice [178]. 
In summary, endosomes are key sites for the localization, recycling and targetingfor-degradation of growth-associated cargo. Regulation of endosome localization and transport in neurons can have key implications for axon growth and regeneration.

\section{Lysosomes and Autophagosomes}

\subsection{Structure and Function}

The lysosome is a dynamic organelle that supports multiple cellular functions. The classical view of lysosomes is that they function for the degradation and recycling of biological macromolecules that are delivered to the lysosome by autophagic, endocytic, and phagocytic routes. However, more recently, lysosomes and late endosomes have emerged as important compartments with roles as platforms for local protein synthesis, in the regulation of gene expression, cell growth, plasma membrane repair, synaptic plasticity, and other functions. Lysosomes are also involved in calcium signaling, lipid signaling, response to injury signaling, and importantly interaction with other organelles (reviewed in [179-182]). Furthermore, lysosomal/late endosomal trafficking is dynamically regulated, and the position of these organelles influences their function in neuronal compartments (reviewed in $[180,183])$. Autophagosomes participate in degradation through gathering cellular material and mitochondria then fusing with lysosomes, but are also an important part of the recycling machinery (reviewed in $[184,185]$ ).

\subsection{Lysosomal Regulation of Autophagy in Axon Growth and Regeneration}

The process of autophagy has been implicated in both neuronal survival and growth. The entry of molecules into autophagosomes can be non-selective, but the autophagic turnover of cell surface molecules involved in axon growth is selective, being regulated by ubiquitination, which is recognized by adaptors on autophagosomes (reviewed in $[184,185])$. In axons, autophagosomes have been observed to mature as they are retrogradely transported towards the cell body where they fuse with lysosomes [186-188]. The majority of autophagosomes are formed at the distal part of the axon near synapses [186-189]. Autophagosomes bud from two sources: Rab11-recycling endosomes [190] and the endoplasmic reticulum [188]. Importantly, the rate of autophagosome generation declines with neuronal maturation [191-195], coinciding with loss of regenerative ability. The fusion of autophagosomes with lysosomes was recently shown to play an important role in axon regeneration [196]. Failure of regeneration in inhibitory scar tissue is associated with the formation of dystrophic endbulbs on cut axons. These are induced by blockade of autophagic flux as autophagosomes fuse with lysosomes $[196,197]$. There are, however, contradicting reports on whether the manipulation of autophagy itself is beneficial or detrimental to the intrinsic growth potential of neurons. These studies are summarized in Table 1. The controversy is further complicated when considering that autophagy-related genes can influence growth via noncanonical pathways [198]. For instance, autophagy influences axon growth by the regulation of microtubule dynamics $[199,200]$ whilst the autophagy-inducing kinases ULK1 and ULK2 have been confirmed to regulate axon growth by autophagy-independent mechanisms [201]. In addition, the function of autophagy differs among developmental maturation ages and in neuron types with different regeneration capacities ([189,199,202]; see also Table 1). Taken together, autophagy has been associated with axon growth and regeneration, functioning through the regulation of various mechanisms and molecules including adhesion complexes, the cytoskeleton, and general metabolism. Whether autophagosome function promotes or inhibits axonal regeneration after injury appears to depend on the status of the neuron, but further studies are needed to determine how autophagic mechanisms can be best targeted for regenerative gain. 
Table 1. Summary of studies that assessed the effect of autophagy on neuronal growth.

\begin{tabular}{|c|c|c|c|c|}
\hline $\begin{array}{c}\text { Method for } \\
\text { Manipulation of } \\
\text { Autophagy } \\
\end{array}$ & Neuronal Type Examined & Species and Age & $\begin{array}{c}\text { Main Findings } \\
\text { Regarding Neuronal } \\
\text { Growth }\end{array}$ & Reference \\
\hline $\begin{array}{l}\text { Knockdown of ATG7 } \\
\text { Application of } \\
\text { 3-methyladenine }\end{array}$ & Primary cortical neurons & $\begin{array}{l}\text { Embryonic rats and } \\
\text { cultured for } 1 \text { till } 3 \text { days }\end{array}$ & $\begin{array}{l}\text { Inhibition of autophagy } \\
\text { resulted in: } \\
\text { - elongation of neurites } \\
\text { in vitro } \\
\text { - reduction of RhoA } \\
\text { signalling }\end{array}$ & Ban et al., 2013 [203] \\
\hline $\begin{array}{l}\text { Knockout of: ATG-2, } \\
\text { ATG9, ATG13, EPG-8, } \\
\text { IGG-1, UNC104 }\end{array}$ & $\begin{array}{l}\text { PVD nociceptive sensory } \\
\text { neuron }\end{array}$ & Larval and adult C. elegans & $\begin{array}{l}\text { Inhibition of autophagy } \\
\text { resulted in: } \\
\text { - elongation of the axon } \\
\text { in vivo }\end{array}$ & Stavoe et al., 2016 [189] \\
\hline Knockout of: WDR47 & $\begin{array}{c}\text { - Primary cortical and } \\
\text { hippocampal neurons } \\
\text { - Callosal and corticofugal } \\
\text { neurons }\end{array}$ & $\begin{array}{l}\text { - Embryonic mice and } \\
\text { cultured for } 4 \text { days } \\
\text { - Adult mice (16 weeks } \\
\text { old) }\end{array}$ & $\begin{array}{l}\text { Activation of autophagy } \\
\text { resulted in: } \\
\text { - Impaired formation and } \\
\text { dynamics of growth cones } \\
\text { in vitro } \\
\text {-Defective and reduction } \\
\text { of axonal projections in the } \\
\text { corpus calossum in vivo } \\
\text { - Destabilisation of } \\
\text { microtubules }\end{array}$ & $\begin{array}{c}\text { Kannan et al., } 2017 \\
\text { [200] }\end{array}$ \\
\hline $\begin{array}{l}\text { Knockout of: ATG-2, } \\
\text { ATG9, ATG13, EPG-8, } \\
\text { IGG-1, UNC104 }\end{array}$ & $\begin{array}{c}\text { - HSN serotonergic motor } \\
\text { neuron } \\
\text { - DA9 cholinergic motor } \\
\text { neuron } \\
\text { - RIA interneuron } \\
\text { - RIB interneuron - NSM } \\
\text { pharyngeal } \\
\text { neurosecretory-motor } \\
\text { neuron }\end{array}$ & Larval and adult C. elegans & $\begin{array}{l}\text { Inhibition of autophagy } \\
\text { resulted in: } \\
\text { - no phenotype in vivo }\end{array}$ & Stavoe et al., 2016 [189] \\
\hline $\begin{array}{l}\text { Application of } \\
\text { Tat-beclin1 }\end{array}$ & $\begin{array}{l}\text { - Primary cortical neurons } \\
\text { - Neuron types with axon } \\
\text { fibres in the spinal cord }\end{array}$ & $\begin{array}{l}\text { - Embryonic rats and } \\
\text { cultured for } 1 \text { till } 3 \text { days } \\
\text { - Adult mice ( } 8 \text { till } 10 \\
\text { weeks old) subjected to } \\
\text { spinal cord hemisection } \\
\text { injury }\end{array}$ & $\begin{array}{l}\text { Activation of autophagy } \\
\text { resulted in: } \\
\text { - enhanced neurite } \\
\text { outgrowth on inhibitory } \\
\text { substrates in vitro } \\
\text { - Inhibition of axonal } \\
\text { retraction after injury in } \\
\text { cortical neurons in vitro } \\
\text { and corticospinal neurons } \\
\text { in vivo } \\
\text { - Stimulation of axonal } \\
\text { regeneration of } \\
\text { monoaminergic neurons } \\
\text { after injury in vivo } \\
\text { - Stabilisation of } \\
\text { microtubules }\end{array}$ & He et al., 2016 [199] \\
\hline $\begin{array}{l}\text { Application of } \\
\text { 3-methyladenine }\end{array}$ & $\begin{array}{l}\text { Dorsal root ganglion } \\
\text { neurons }\end{array}$ & $\begin{array}{l}\text { Adult rat (4 till } 5 \text { weeks } \\
\text { old) and cultured for } 1 \text { day }\end{array}$ & $\begin{array}{c}\text { Inhibition of autophagy } \\
\text { resulted in: } \\
\text { - Reduction of neuronal } \\
\text { survival } \\
\text { - Inhibition of neurite } \\
\text { growth and branching }\end{array}$ & $\begin{array}{c}\text { Clarke and Mearow, } 2016 \\
\text { [204] }\end{array}$ \\
\hline
\end{tabular}

This table highlights that autophagosomes control axon growth and regeneration in neurons. The function of autophagy differs among neuron types and developmental maturation ages. However, the contradictory findings between the studies could also be the result of targeting different components of the autophagy machinery. It also cannot be excluded that the manipulated molecules influence axon growth via noncanonical pathways. The main results for each study are summarized and the colors indicate whether autophagy was considered negative (orange), had no effect (white), or positive (green) for axon growth and regeneration in the mentioned neuron type and age. 


\subsection{Lysosome/Endosome Regulation of Intracellular Pathways in Axon Growth and Regeneration}

Recent work has identified various ways in which lysosomes and late endosomes can affect axon growth and regeneration by acting as molecular platforms for key signaling pathways. One of the most well-studied pathways in this regard is the PI3K to mTOR pathway. mTOR (mammalian target of rapamycin) is a serine/threonine protein kinase that is localized on the outer surface of the lysosome. Acting through mTOR complexes 1 and 2, mTOR influences fundamental cell processes, leading to the regulation of protein synthesis, metabolism, and autophagosome generation (reviewed in [205-207]). There are many molecular mechanisms that influence the activation state of mTOR and are known to influence axon regeneration after injury in vivo. For instance, PTEN (phosphatase and tensin homolog), TSC1 (tuberous sclerosis complex 1), TSC2 (tuberous sclerosis complex 2) and GSK3 (glycogen synthase kinase) are negative regulators of mTOR activity and their genetic deletion in transgenic mice promoted axon regeneration in various models of traumatic nervous system injuries [18,19,208-212]. Axon regeneration in the CNS can also be achieved by delivering positive regulators of mTOR activity such as AKT [213], wnt10b (Wnt family member10b) [214], a specific mutant of HDAC (Class II histone deacetylase 5) [215], or PI3K delta [20] among others. Ageing is another important factor influencing mTOR. It was shown in RGCs and cortical neurons that mTOR signaling declines during maturation in line with their regeneration capacity [18-20]. Taken together, it is well established that mTOR activation in neurons is an important driver for axon regeneration. However, mTOR-activation and signaling occurs on the surface of late endosomes and lysosomes, so these organelles must be present in the tips of axons in order for local signaling to occur. In addition, mTOR was found to specifically localized at the growth cones of developing callosal projection neurons where it was necessary for axon extension [216].

\subsection{Lysosome/Late Endosome Regulation of Exocytosis for Axon Growth and Regeneration}

Exocytosis from lysosomes is another important mechanism that contributes to membrane repair and axon growth. As discussed already, intracellular free calcium is an important secondary messenger and one of its functions is to initiate exocytosis from lysosomes to other intracellular organelles and the extracellular space [217-224]. Exocytosis from lysosomes has been shown to contribute to neurite outgrowth in primary neuronal cultures derived from superior cervical ganglion [220], hippocampus [222], and cortex [224]. The $\mathrm{Ca}^{2}$-dependent exocytosis of lysosomes participates, together with ER, multivesicular bodies and other endosomes, in the addition of new membrane for axon growth and resealing of plasma membrane in case of an injury. Importantly, lysosomal exocytosis may also contribute to axon elongation by making the extracellular matrix more growth permissive by the secretion of lysosome-associated proteins. For instance, it was shown that lysosomal exocytosis results in the release of ATP [225] (which could act as an extracellular signaling molecule), the lysosomal enzyme acid sphingomyelinase [226] and various lysosomal cysteine proteases [223,227], which can modify the extracellular matrix.

In summary, autophagosomes and lysosomes/late endosomes contribute to axon growth and regeneration by the regulation of multiple processes including autophagy, intracellular signaling and exocytosis.

\section{Proteasome}

\subsection{Structure and Function}

The proteasome is a membrane-bound organelle which has an essential role in the clearance of excessive or damaged proteins [228]. It consists of several catalytic units which form a large cytoplasmic complex. Proteasomes recognize polyubiquitinated proteins and degrade them for clearance. Proteasomal distribution along the axon is key to proper neuronal development and maturation [229]. Mice lacking the adaptor protein PI31, which is essential for proteasome translocation to the distal axon, show disrupted synaptic structures and reduced survival highlighting the importance of the proteasome in protein 
degradation in axonal development [230]. In the axon, proteasomes are transported in anterograde and retrograde direction along microtubule tracts with the help of motor proteins with dynamics that resemble membrane vesicle movement and association with intracellular membranes [231]. At dendritic spines, fast activity-dependent recruitment of proteasomes has been implicated as an essential mechanism of protein degradation and this is important for the formation and maintenance of synapses (reviewed in [232-234]).

\subsection{Protein Degradation by the Proteasome in Developmental Axon Growth}

Proteasomes have an important role in neurite outgrowth. This was first described in the early 1990s, when application of the proteasome inhibitor lactacystin induced neurite outgrowth in PC12 cells and in neuroblastoma cell-lines [235-237]. Treatment of NGF in PC12s cells induces neurite outgrowth and was shown to reduce proteasomal activity by changing its catalytic unit composition. In primary neurons though, pre-treatment with proteasome inhibitors completely ablates axon formation and low concentrations of inhibitors reduced axon elongation and branching [238]. In addition, treatment of sympathetic and sensory neuronal explants with lactacystin, applied at the same concentrations as used for neurite outgrowth induction in PC12 cells, resulted in neurite extension block, which subsequently results in neurodegeneration [239]. These studies suggest that in neurons, basal level proteasome function is required for developmental axon growth. The role of the proteasome in neurodegeneration is extensive and is summarized elsewhere [240-242].

One mechanism through which proteasomal manipulation can influence neurite outgrowth is through the regulation of protein degradation at the growth cone. For example, Akt signaling phosphorylates radixin, a protein which tethers F-actin to the plasma membrane during growth, at a specific residue that protects it from proteasomal degradation. This resulted in stabilized interaction with F-actin and proper neurite outgrowth and growth cone formation [243]. In addition, the ubiquitin ligase Rnf6, which is expressed in both sensory and motor axons, specifically targets LIMK1 for degradation by the proteasome. LIMK1 plays an important role in regulation of the actin cytoskeleton during growth suggesting a role for the ubiquitin/proteasome system in regulating local cytoskeleton growth cone dynamics [244]. The proteasome also contributes to the establishment of neuronal polarity as inhibition of the proteasome results in a uniform rather than axon-confined distribution of Akt, which, in turn, results in the formation of multiple axons [245]. The ubiquitin-proteasome system was also recently implicated in axon guidance as Sema-3A, a secreted growth-repulsive guidance cue, was shown to promote FMRP (an RNA-binding protein involved in axon growth) proteasomal degradation in growth cones [246]. FMRP degradation in turn, led to growth cone collapse and turning away from repulsive cues [246].

\subsection{Protein Degradation by the Proteasome in Axon Regeneration}

The ability of axons to form a new growth cone and to regenerate after injury is dependent on local protein synthesis and degradation [74,247]. Application of protein synthesis and proteasome inhibitors to either whole or axon-only preparations of injured DRG or retinal axons in vitro prevented them from forming a new growth cone suggesting a role for protein turnover near the injury site for successful regeneration [74]. In ligated sciatic nerve, proteasomes accumulated proximally to the ligation but not distally, suggesting that the ligation obstructed anterograde axonal transport of the proteasome [231]. Interestingly, protein synthesis machinery was found at higher levels in PNS neurons compared to CNS neurons, whereas proteasome components showed the opposite distribution with higher levels in the CNS [74]. In fact, in conditioned DRGs which mount a robust regenerative response, the proteasome machinery load was reduced [74], indicating that protein balance is essential for axon regeneration. A similar decrease in axonal proteasome levels due to increased retrograde transport was observed early on in axon development of hippocampal neurons in vitro and in the cortex in vivo [248], further suggesting the localization of proteasomes in the axon could be inhibitory for growth. The removal of proteasomes from the 
newly growing axon can be triggered by pro-growth influences such as BDNF and cAMP suggesting the need for protein degradation downregulation in order to achieve protein stability during axon development [248]. Blockade of retrograde proteasomal transport resulted in proteasome accumulation at the axon tip and this reduced axonal growth [248]. Another growth factor-TGF-beta-was shown to inhibit proteasomal function, which increased neurite regeneration after scratch lesion in primary midbrain cultures [249]. Peripheral nerve injury was shown to evoke calcium influx into axons, which, in turn, activated the proteasome to degrade ubiquitinated proteins [250]. In particular, this activation of the proteasome at the site of injury resulted in neurofilament degradation and triggered Wallerian degeneration [250]. In a different injury paradigm, proteasomal activation due to transient axonal stretch injury primary cortical neurons prevented secondary injury, likely through effects on stabilizing the cytoskeleton. In this case, proteasomal activation was protective [251].

The studies above suggest that proteasomal activity in the axon requires a critical level of regulation and plays an essential role in protein balance in newly growing and regenerating axons. Further studies are needed to uncover how the proteasome can be targeted to promote growth and axon regeneration after injury.

\section{Organellar Interconnections}

Membrane-bound organelles allow the cell to perform multiple, incompatible biochemical processes in separated compartments, but at the same time require intricate levels of synchronicity and regulation. Inter-organellar interactions have been historically difficult to study due to their dynamic nature and due to their low temporal and spatial resolution. Only recently, with the advancement of high-resolution microscopy, could the complexity of this interconnectivity be studied $[25,26]$. In fibroblasts, multi-level interactions between six different organelles were recently observed by confocal and lattice light sheet microscopy [252]. These studies revealed that each organelle has a unique distribution pattern in the cell but at different points in time, some organelles come into contact with each other to perform a specific joint function [252]. Focused ion beam-scanning electron microscopy allowed for the 3D reconstruction of organelles in neurons and showed complex interactions between the continuous endoplasmic reticulum and an array of other organelles [31]. Membrane contact sites (MCS) are described as close membrane appositions (10-30 $\mathrm{nm}$ ) between the outer lipid layers of two membrane-bound organelles and these are essential for inter-organellar signaling and function. MCSs have recently been investigated in the context of axon growth and regeneration [253,254]. MCS are not merely physical interactions between organellar membranes-they can often be enriched in various proteins and tightly regulated depending on the physiological conditions of the cell [255]. In fact, mutations in many proteins stabilizing MCSs have been described as causative in human axonal disease (Table 2) suggesting a role for organelle-organelle interactions in the processes of neuronal development, growth and regeneration.

Table 2. Table summarizing human conditions caused by genetic deficits in genes important for MCSs between organelles.

\begin{tabular}{ccccc}
\hline Membrane Contact Site & Disease & Genes Involved & Gene Function & References \\
\hline $\begin{array}{c}\text { ER- Endosomes/ } \\
\text { ER-PM/ER-Lysosome }\end{array}$ & $\begin{array}{c}\text { Hereditary Spastic } \\
\text { Paraplegia }\end{array}$ & Zfyve27 & $\begin{array}{c}\text { Vesicular membrane } \\
\text { trafficking, ER- } \\
\text { endosome/lysosome } \\
\text { tethering }\end{array}$ & $\begin{array}{c}\text { Mannan et al., 2006 } \\
\text { [256] }\end{array}$ \\
ER-Endosome & $\begin{array}{c}\text { Hereditary Spastic } \\
\text { Paraplegia }\end{array}$ & Spastin & Microtubule-severing \\
protein & Evans et al., 2006 [257] \\
ER-Mitochondria & $\begin{array}{c}\text { Hereditary Spastic } \\
\text { Paraplegia }\end{array}$ & REEP1 & Microtubule- & $\begin{array}{c}\text { Zuchner et al., 2006; } \\
\text { Beetz et al., 2008 } \\
\text { mitochondria }\end{array}$ \\
\hline
\end{tabular}


Table 2. Cont.

\begin{tabular}{|c|c|c|c|c|}
\hline Membrane Contact Site & Disease & Genes Involved & Gene Function & References \\
\hline ER-Endosome/ER-PM & $\begin{array}{l}\text { Amyotrophic Lateral } \\
\text { Sclerosis }\end{array}$ & VAP-A, VAP-B & $\begin{array}{l}\text { ER-organelle tethering, } \\
\text { facilitate protein } \\
\text { interaction, vesicular } \\
\text { trafficking }\end{array}$ & $\begin{array}{l}\text { Nishimura et al., } 2004 \\
\text { [260] }\end{array}$ \\
\hline ER-Mitochondria & $\begin{array}{l}\text { Early onset autosomal } \\
\text { Parkinson's disease }\end{array}$ & PARKIN, PINK1 & $\begin{array}{l}\text { Mitochondrial quality } \\
\text { control and turnover }\end{array}$ & $\begin{array}{c}\text { Kitada et al., 1998; } \\
\text { Valente et al., 2004a; } \\
\text { Valente et al., 2004b } \\
\text { [261-263] }\end{array}$ \\
\hline ER-Mitochondria & $\begin{array}{c}\text { Charcot Marie Tooth } \\
\text { Disease }\end{array}$ & MFN-2 & $\begin{array}{l}\text { Mitochondrial fusion, } \\
\text { interaction with } \\
\text { endoplasmic reticulum }\end{array}$ & $\begin{array}{l}\text { Zuchner et al., } 2004 \\
\text { [264] }\end{array}$ \\
\hline ER-Mitochondria & $\begin{array}{c}\text { Charcot Marie Tooth } \\
\text { Disease }\end{array}$ & DNM-2 & $\begin{array}{l}\text { Vesicle trafficking, } \\
\text { cytoskeleton dynamics, } \\
\text { endosomal pathways }\end{array}$ & $\begin{array}{c}\text { Sidiropoulos et al., } 2012 \\
\text { [265] }\end{array}$ \\
\hline ER-PM & $\begin{array}{c}\text { Tubular Aggregate } \\
\text { Myopathy }\end{array}$ & STIM-1 & Calcium sensor & Bohm et al., 2017 [266] \\
\hline
\end{tabular}

This table highlights that mutations in genes which are important at MCSs between organelles could lead to human axonal disease. Additional gene functions are also listed.

\subsection{ER-Mitochondria Interactions}

The ER and mitochondria form contacts at mitochondrial-associated membranes (MAMs) and are essential for a number of cellular functions such as calcium homeostasis, regulation of apoptosis, lipid synthesis and trafficking and energy production (reviewed in [267-274]). Defective ER-mitochondria linkage has recently been implicated in several neurodegenerative conditions underlying its importance for axon maintenance [275-279]. Grp75 is a protein linker found at MAMs that initiates contact between IP3R in the ER and VDAC1 in the mitochondria. These contacts regulate calcium transfer between the two organelles [280]. Grp75 mRNA is upregulated upon axonal injury in the PNS [72] and local axonal synthesis of Grp75 is initiated as a response in primary hippocampal neurons after injury [253]. Grp75 deletion leads to abnormal axon development, while its overexpression prompts increased association between ER and mitochondria in injured hippocampal neurons in vitro and in sciatic nerves after sciatic nerve injury in vivo [253]. Both experiments showed that increased interconnection between ER and mitochondria improved calcium buffering and potentiated ATP production, which ultimately led to increased levels of axon regeneration and functional recovery after injury [253]. Interestingly, mitochondrial tethering to Grp75 at the growing tip of neurites improves axon outgrowth in cultured cortical neurons [281]. Another protein present at the ER-mitochondria interface is REEP1. REEP1, an ER-shaping protein responsible for axon growth and maintenance, but it also contains mitochondria-linking subdomains that may aid growth as well. Overexpression of disease-associated mutant REEP1 in mouse cortical neurons reduced dendritic tree complexity as a result of decreased ER-mitochondria tethering [45].

\subsection{ER-Lysosomes/Late Endosomes Interactions}

MCSs between endoplasmic reticulum and the endocytic pathways have emerged as regulators of endosomal function and localization, and their association is normally microtubule-associated and increases as endosomes mature [282,283]. Interestingly, ER tubule positioning along the axon and its morphology were recently shown to depend on motile lysosomes in response to chemical, light or metabolic stimuli [284]. Ablation of ER-lysosome MCS protein, VAP-A, resulted in ER fragmentation and reduced axonal length in growing RGC axons [284]. The molecular composition of MCSs between ER and lysosomes/late endosomes is still not very well studied. One protein shown to modulate the interaction between the ER and late endosomes (LE) is ER-resident protein Protrudin. Protrudin recognizes specific phosphoinositides and Rab7 on late endosomes and tethers them to the ER [285]. Protrudin then acts as an adaptor to facilitate the loading 
of kinesin-1 from the ER onto the motor adaptor-FYCO1—which is located on Rab7positive LEs [285]. This process of repeated ER-LE contacts results in the anterograde transport of late endosomes along microtubules towards the cell periphery and is essential for protrusion formation and neurite outgrowth [285]. Overexpression of protrudin in RPE1 or PC12 cells induced long protrusions in a Rab7 and kinesin-dependent manner. Synaptotagmin- 1 assisted this process by allowing the fusion of late endosomes and the plasma membrane. Over expression or activation of Protrudin in mature CNS axons also facilitates robust long-range regeneration, but whether this process relies on increased lysosomal transport has not been reported. The interaction between Protrudin and the ER MCS VAP proteins (VAP-A and-B) is required, because genetic interference with this interaction hinders the protrudin's regenerative actions [43].

In addition, the endosomal protein IST1 and ER-localized isoform of spastin, a microtubule-severing protein, act at ER-endosome MCSs to promote endosomal fission [286,287]. Defects in this system lead to abnormal protein sorting and lysosomal dysfunction in primary cortical neurons and iPSC-derived neurons from HSP patients with spastin mutations [287]. As a result, the link between ER-regulated endosomal fission at MCSs and lysosomal function was proposed as a major mechanism of axon degeneration in HSP. In addition, ER-endosomal interaction has been shown to play an important role in receptor signaling. For example, once activated on the cell surface, the EGFR receptor is internalized in endosomes and continues signaling until dephosphorylated by PTP1B at ERendosome contact sites $[288,289]$. ER-endosome contact sites were shown to be regulated by TPC1—an endo-lysosomal ion channel controlled by calcium signaling. Reduced MCS formation resulted in decreased endosome to ER contact and prolonged EGFR signaling, suggesting the role of MCSs as calcium-dependent hubs for signaling [290]. Receptor signaling timing and calcium influx play critical roles in axon growth and regeneration, but it is yet to be studied whether the mechanisms of ER-endosomes play a role in neurons. In addition, a novel regulator of ER-endosome contact sites was recently described. TMEM16K on the ER interacts with Rab7 on late endosomes to initiate MCS formation [291]. Loss of TMEM16K leads to impaired endo-lysosomal transport and function as well as neuromuscular and motor deficits in mice [291].

Recent studies implicated PDZD8, an ER-associated protein, and Protrudin together with the late endosomal protein Rab7 as main components of ER-endosome contact sites [292]. PDZD8 is also a component of the ER-mitochondria MCSs [293] and enables the recruitment of mitochondria to ER-endosomal MCS in order to regulate lipid transport and endosomal function [292]. Studying the significance of such complex inter-organellar interactions facilitated by multiple proteins in the context of axon growth and regeneration will be an interesting future area of research.

\subsection{Endosome/Lysosome-Mitochondria Interactions}

Endosome-mitochondria tethering also plays an important role in axon growth and integrity. One way through which this could occur is by regulation of protein translation. For example, RNA granules have previously been reported to tether to lysosomes which provide a platform for mRNA long-range transport along the axon [294]. In addition, Rab7-positive endosomes in contact with ribonucleoprotein particles often dock onto mitochondria in order to secure energy for local protein translation [30]. A mutation in Rab7, which is associated with Charcot-Marie-Tooth disease, results in defective binding of Rab7-endosomes to mitochondria, resulting in reduced protein synthesis in the axon and compromised axon integrity after initial axon outgrowth in RGCs [30]. Interestingly, ER is also found to be in close proximity to mRNA granules and late endosomes [30]. They form MCSs near processing bodies that carry mRNAs around the cells regulating their dynamics and translocation [295]. This all suggests a possible involvement of mitochondria and ER in endosomal trafficking or regulation of mRNA translation during growth which may have implications for regeneration in the CNS. 
Mitochondrial interaction with the autophagosome-lysosome system is crucial for the process of mitophagy where depolarized mitochondria are actively degraded. Some studies point towards retrograde transport of damaged mitochondria to be coupled with mature lysosomes in the soma for degradation $[296,297]$. In fact, damaged mitochondria were shown to bulk release mitochondria-anchoring protein syntaphilin and these are transported to the cell body for degradation via interaction with late endosomes [298]. This process was found to be essential for survival in neurons upon ischemic injury and during neurodegeneration $[298,299]$. In addition, others have documented that dysfunctional mitochondria stalled in the distal axon, which suggests that local clearance might also occur independently of retrograde transport [300]. Indeed, in rat hippocampal neurons, triggering mitochondrial damage at physiological levels in the distal axon results in the recruitment of LC3-positive autophagosomes, LAMP1-positive lysosomes and Parkin, an E3 ubiquitin ligase for local degradation of damaged mitochondria [301]. As mentioned in Section 3, mitochondria depolarize after axonal injury, so their removal plays an essential role in axon regeneration. Further studies are needed to characterize the exact role of mitochondria-autophagosome-lysosome connection in axon growth and regeneration.

\subsection{Proteasome-Other Organelles}

A proportion of proteasomes in cultured neurons was also shown to form connections with lysosomes, which might play a role for the retrograde transport from dendritic spines to the cell body. In addition, the proteasome was shown to make contacts with synaptic vesicles, Golgi-derived vesicles and with mitochondria [231]. Recently, live-cell imaging in hippocampal neurons revealed that proteasomal inhibition impairs the axonal transport of APP by stimulating its trafficking to the endo-lysosomal system for cleavage. This study underlines the importance of proteasome-lysosome crosstalk and implicated proteasomal dysfunction in the abnormal APP metabolism causing axonal degeneration in some neurodegenerative diseases [302].

\section{Conclusions}

Axon growth and regeneration are cellular processes that involve signaling from the growth cone, or the site of injury back to the cell body via signaling endosomes. They, in turn, instruct changes in gene expression and axonal transport via the endosomal system as well as in protein synthesis, distribution and turnover through the ER, lysosome and autophagosome. This results in growth-related cargo translocation to the growth cone, the generation of energy supply through the mitochondria and intracellular signaling for membrane expansion and targeted growth. All these processes need to exist in concert to elicit successful growth and regeneration programs. Our understanding of cellular organelles has dramatically changed over the past decade from individual, isolated compartments, carrying out specific functions to highly interconnected and dynamic networks that regulate cascades of molecular events in three dimensions within the cell. Individually, organelles have been extensively studied in the context of axon growth and regeneration where they play key roles in the growth process by acting as molecular platforms to housing, distributing and regulating numerous intracellular molecules, materials and signaling components. Only recently with the advancement of high-resolution microscopy, the intricate interactions between different organelles or networks of organelles were made possible to study. We propose a model in which organelle contact sites orchestrate highly dynamic and interconnected series of molecular and cellular events that influence, and are needed, for axon growth and regeneration (Figure 1). Future efforts should be centered to studying these connections between organelles in the context of axon regeneration, where they could potentially serve as therapeutic targets to improve the intrinsic regenerative capacity of adult CNS neurons. 


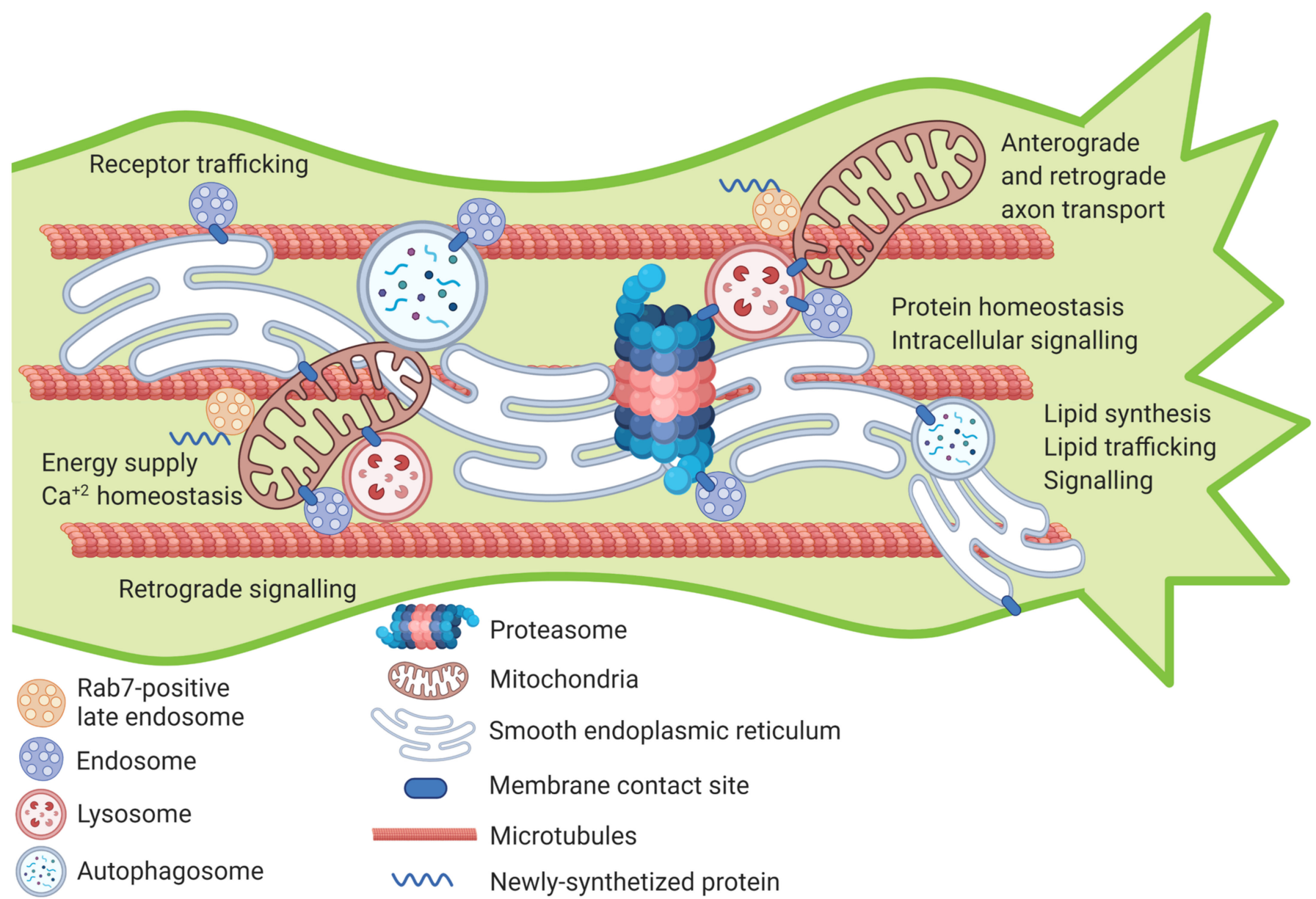

Figure 1. Proposed model for inter-organellar interactions within the axon shaft. Within the cell, various organelles form transient or permanent interactions with each other. Many of these organellar inter-connections have previously been documented in the axon (such as ER-mitochondria, ER-lysosome, ER-endosome, mitochondria-lysosome) but some are yet to be studied. This model proposes that membrane-contact sites between pairs of organelles or multiple organelles could occur in the axon shaft near the growth cone of developing or regenerating axons. These interactions play an essential role in numerous processes involved in axon growth and regeneration such as lipid signaling and trafficking, protein turnover, intracellular signaling, calcium buffering, receptor trafficking and energy homeostasis. Future studies on the developmental regulation of the quantity and dynamics of inter-organelle membrane contact sites could provide clues on how they can be targeted to boost axon growth and regeneration. Figure created with BioRender.com (www.biorender.com [last accesses 18 January 2021]).

Author Contributions: V.P. and B.N. carried out extensive literature search and wrote the initial draft of this article. V.P., B.N., J.W.F. and R.E. all were involved in editing and curating the article for final submission. All authors have read and agreed to the published version of the manuscript.

Funding: This review was funded by the Medical Research Council (MR/R004544/1, MR/R004463/1), Czech Ministry of Education (CZ.02.1.01/0.0./0.0/15_003/0000419), International Foundation for Research in Paraplegia, EU ERA-NET NEURON (AxonRepair grant), Fight for Sight (5119/5120, and 5065-5066), Wings for Life (WFL GB-04/19) and National Eye Research Council.

Conflicts of Interest: Authors declare no conflict of interest.

\section{References}

1. Banker, G. The development of neuronal polarity: A retrospective view. J. Neurosci. 2018, 38, 1867-1873. [CrossRef] [PubMed]

2. Schelski, M.; Bradke, F. Neuronal polarization: From spatiotemporal signaling to cytoskeletal dynamics. Mol. Cell. Neurosci. 2017, 84, 11-28. [CrossRef] [PubMed]

3. Dotti, C.G.; Sullivan, C.A.; Banker, G.A. The establishment of polarity by hippocampal neurons in culture. J. Neurosci. 1988, 8, 1454-1468. [CrossRef] 
4. Esch, T.; Lemmon, V.; Banker, G. Local presentation of substrate molecules directs axon specification by cultured hippocampal neurons. J. Neurosci. 1999, 19, 6417-6426. [CrossRef]

5. O'Donnell, M.; Chance, R.K.; Bashaw, G.J. Axon Growth and Guidance: Receptor Regulation and Signal Transduction. Annu. Rev. Neurosci. 2009, 32, 383-412. [CrossRef]

6. Pfenninger, K.H. Plasma membrane expansion: A neuron's Herculean task. Nat. Rev. Neurosci. 2009, 10, 251-261. [CrossRef] [PubMed]

7. Shen, K.; Scheiffele, P. Genetics and cell biology of building specific synaptic connectivity. Annu. Rev. Neurosci. 2010, 33, 473-507. [CrossRef]

8. Lu, Y.; Brommer, B.; Tian, X.; Krishnan, A.; Meer, M.; Wang, C.; Vera, D.L.; Zeng, Q.; Yu, D.; Bonkowski, M.S.; et al. Reprogramming to recover youthful epigenetic information and restore vision. Nature 2020, 588, 124-129. [CrossRef]

9. Hilton, B.J.; Bradke, F. Can injured adult CNS axons regenerate by recapitulating development? Development 2017, 144, 3417-3429. [CrossRef]

10. He, Z.; Jin, Y. Intrinsic Control of Axon Regeneration. Neuron 2016, 90, 437-451. [CrossRef]

11. Kiyoshi, C.; Tedeschi, A. Axon growth and synaptic function: A balancing act for axonal regeneration and neuronal circuit formation in CNS trauma and disease. Dev. Neurobiol. 2020, 80, 277-301. [CrossRef]

12. Petrova, V.; Eva, R. The Virtuous Cycle of Axon Growth: Axonal Transport of Growth-Promoting Machinery as an Intrinsic Determinant of Axon Regeneration. Dev. Neurobiol. 2018, 78, 898-925. [CrossRef]

13. Schwab, M.E.; Strittmatter, S.M. Nogo limits neural plasticity and recovery from injury. Curr. Opin. Neurobiol. 2014, 27, 53-60. [CrossRef]

14. Bradke, F.; Fawcett, J.W.; Spira, M.E. Assembly of a new growth cone after axotomy: The precursor to axon regeneration. Nat. Rev. Neurosci. 2012, 13, 183-193. [CrossRef] [PubMed]

15. Ziv, N.E.; Spira, M.E. Localized and transient elevations of intracellular Ca2+ induce the dedifferentiation of axonal segments into growth cones. J. Neurosci. 1997, 17, 3568-3579. [CrossRef]

16. Chandran, V.; Coppola, G.; Nawabi, H.; Omura, T.; Versano, R.; Huebner, E.A.; Zhang, A.; Costigan, M.; Yekkirala, A.; Barrett, L.; et al. A Systems-Level Analysis of the Peripheral Nerve Intrinsic Axonal Growth Program. Neuron 2016, 89, 956-970. [CrossRef] [PubMed]

17. Costigan, M.; Befort, K.; Karchewski, L.; Griffin, R.S.; D’Urso, D.; Allchorne, A.; Sitarski, J.; Mannion, J.W.; Pratt, R.E.; Woolf, C.J. Replicate high-density rat genome oligonucleotide microarrays reveal hundreds of regulated genes in the dorsal root ganglion after peripheral nerve injury. BMC Neurosci. 2002, 3, 16. [CrossRef] [PubMed]

18. Park, K.K.; Liu, K.; Hu, Y.; Smith, P.D.; Wang, C.; Cai, B.; Xu, B.; Connolly, L.; Kramvis, I.; Sahin, M.; et al. Promoting Axon Regeneration in the Adult CNS by Modulation of the PTEN/mTOR Pathway. Science 2008, 322, 963-966. [CrossRef]

19. Liu, K.; Lu, Y.; Lee, J.K.; Samara, R.; Willenberg, R.; Sears-Kraxberger, I.; Tedeschi, A.; Park, K.K.; Jin, D.; Cai, B.; et al. PTEN deletion enhances the regenerative ability of adult corticospinal neurons. Nat. Neurosci. 2010, 13, 1075-1081. [CrossRef] [PubMed]

20. Nieuwenhuis, B.; Barber, A.C.; Evans, R.S.; Pearson, C.S.; Fuchs, J.; MacQueen, A.R.; Erp, S.; Haenzi, B.; Hulshof, L.A.; Osborne, A.; et al. PI 3-kinase delta enhances axonal $\mathrm{PIP}_{3}$ to support axon regeneration in the adult CNS. EMBO Mol. Med. 2020, 12 , e11674. [CrossRef]

21. Sun, F.; Park, K.K.; Belin, S.; Wang, D.; Lu, T.; Chen, G.; Zhang, K.; Yeung, C.; Feng, G.; Yankner, B.A.; et al. Sustained axon regeneration induced by co-deletion of PTEN and SOCS3. Nature 2011, 480, 372-375. [CrossRef]

22. Smith, P.D.; Sun, F.; Park, K.K.; Cai, B.; Wang, C.; Kuwako, K.; Martinez-Carrasco, I.; Connolly, L.; He, Z. SOCS3 Deletion Promotes Optic Nerve Regeneration In Vivo. Neuron 2009, 64, 617-623. [CrossRef] [PubMed]

23. Dupraz, S.; Grassi, D.; Bernis, M.E.; Sosa, L.; Bisbal, M.; Gastaldi, L.; Jausoro, I.; Caceres, A.; Pfenninger, K.H.; Quiroga, S. The TC10-Exo70 Complex Is Essential for Membrane Expansion and Axonal Specification in Developing Neurons. J. Neurosci. 2009, 29, 13292-13301. [CrossRef]

24. Porter, K.R.; Blum, J. A study in microtomy for electron microscopy. Anat. Rec. 1953, 117, 685-709. [CrossRef] [PubMed]

25. Nixon-Abell, J.; Obara, C.J.; Weigel, A.V.; Li, D.; Legant, W.R.; Xu, C.S.; Pasolli, H.A.; Harvey, K.; Hess, H.F.; Betzig, E.; et al. Increased spatiotemporal resolution reveals highly dynamic dense tubular matrices in the peripheral ER. Science 2016, 354, aaf3928. [CrossRef] [PubMed]

26. King, C.; Sengupta, P.; Seo, A.Y.; Lippincott-Schwartz, J. ER membranes exhibit phase behavior at sites of organelle contact. Proc. Natl. Acad. Sci. USA 2020, 117, 7225-7235. [CrossRef] [PubMed]

27. Tsukita, S.; Ishikawa, H. Three-Dimensional Distributionof Smooth Endoplasmic Reticulum in Myelinated Axons. J. Electron Microsc. 1976, 25, 141-149.

28. Droz, B.; Rambourg, A.; Koenig, H.L. The smooth endoplasmic reticulum: Structure and role in the renewal of axonal membrane and synaptic vesicles by fast axonal tranport. Brain Res. 1975, 93, 1-13. [CrossRef]

29. González, C.; Cánovas, J.; Fresno, J.; Couve, E.; Court, F.A.; Couve, A. Axons provide the secretory machinery for trafficking of voltage-gated sodium channels in peripheral nerve. Proc. Natl. Acad. Sci. USA 2016, 113, 1823-1828. [CrossRef]

30. Cioni, J.-M.; Lin, J.Q.; Holtermann, A.V.; Koppers, M.; Jakobs, M.A.H.; Azizi, A.; Turner-Bridger, B.; Shigeoka, T.; Franze, K.; Harris, W.A.; et al. Late Endosomes Act as mRNA Translation Platforms and Sustain Mitochondria in Axons. Cell 2019, 176, 56-72.e15. [CrossRef] 
31. Wu, Y.; Whiteus, C.; Xu, C.S.; Hayworth, K.J.; Weinberg, R.J.; Hess, H.F.; De Camilli, P. Contacts between the endoplasmic reticulum and other membranes in neurons. Proc. Natl. Acad. Sci. USA 2017, 114, E4859-E4867. [CrossRef]

32. Öztürk, Z.; O’Kane, C.J.; Pérez-Moreno, J.J. Axonal Endoplasmic Reticulum Dynamics and Its Roles in Neurodegeneration. Front. Neurosci. 2020, 14, 48. [CrossRef] [PubMed]

33. Westrate, L.M.; Lee, J.E.; Prinz, W.A.; Voeltz, G.K. Form follows function: The importance of endoplasmic reticulum shape. Annu. Rev. Biochem. 2015, 84, 791-811. [CrossRef]

34. Zhang, H.; Hu, J. Shaping the Endoplasmic Reticulum into a Social Network. Trends Cell Biol. 2016, 26, 934-943. [CrossRef] [PubMed]

35. Hübner, C.A.; Kurth, I. Membrane-shaping disorders: A common pathway in axon degeneration. Brain 2014, $137,3109-3121$. [CrossRef] [PubMed]

36. Blackstone, C. Cellular Pathways of Hereditary Spastic Paraplegia. Annu. Rev. Neurosci. 2012, 35, 25-47. [CrossRef]

37. Blackstone, C.; O’Kane, C.J.; Reid, E. Hereditary spastic paraplegias: Membrane traffic and the motor pathway. Nat. Rev. Neurosci. 2011, 12, 31-42. [CrossRef]

38. Yalçın, B.; Zhao, L.; Stofanko, M.; O’Sullivan, N.C.; Kang, Z.H.; Roost, A.; Thomas, M.R.; Zaessinger, S.; Blard, O.; Patto, A.L.; et al. Modeling of axonal endoplasmic reticulum network by spastic paraplegia proteins. Elife 2017, 6, e23882. [CrossRef]

39. O'Sullivan, N.C.; Jahn, T.R.; Reid, E.; O'Kane, C.J. Reticulon-like-1, the Drosophila orthologue of the Hereditary Spastic Paraplegia gene reticulon 2, is required for organization of endoplasmic reticulum and of distal motor axons. Hum. Mol. Genet. 2012, 21, 3356-3365. [CrossRef]

40. Oliva, M.K.; Pérez-Moreno, J.J.; O’Shaughnessy, J.; Wardill, T.J.; O’Kane, C.J. Endoplasmic Reticulum Lumenal Indicators in Drosophila Reveal Effects of HSP-Related Mutations on Endoplasmic Reticulum Calcium Dynamics. Front. Neurosci. 2020, 14, 816. [CrossRef]

41. English, A.R.; Voeltz, G.K. Endoplasmic reticulum structure and interconnections with other organelles. Cold Spring Harb. Perspect. Biol. 2013, 5, 1-16. [CrossRef] [PubMed]

42. Farías, G.G.; Fréal, A.; Tortosa, E.; Stucchi, R.; Pan, X.; Portegies, S.; Will, L.; Altelaar, M.; Hoogenraad, C.C. Feedback-Driven Mechanisms between Microtubules and the Endoplasmic Reticulum Instruct Neuronal Polarity. Neuron 2019, 102, 184-201.e8. [CrossRef] [PubMed]

43. Petrova, V.; Pearson, C.S.; Ching, J.; Tribble, J.R.; Solano, A.G.; Yang, Y.; Love, F.M.; Watt, R.J.; Osborne, A.; Reid, E.; et al. Protrudin functions from the endoplasmic reticulum to support axon regeneration in the adult CNS. Nat. Commun. 2020, 11, 5614. [CrossRef] [PubMed]

44. Park, S.H.; Zhu, P.P.; Parker, R.L.; Blackstone, C. Hereditary spastic paraplegia proteins REEP1, spastin, and atlastin-1 coordinate microtubule interactions with the tubular ER network. J. Clin. Investig. 2010, 120, 1097-1110. [CrossRef] [PubMed]

45. Lim, Y.; Cho, I.T.; Schoel, L.J.; Cho, G.; Golden, J.A. Hereditary spastic paraplegia-linked REEP1 modulates endoplasmic reticulum/mitochondria contacts. Ann. Neurol. 2015, 78, 679-696. [CrossRef] [PubMed]

46. Rao, K.; Stone, M.C.; Weiner, A.T.; Gheres, K.W.; Zhou, C.; Deitcher, D.L.; Levitan, E.S.; Rolls, M.M. Spastin, atlastin, and ER relocalization are involved in axon but not dendrite regeneration. Mol. Biol. Cell 2016, 27, 3245-3256. [CrossRef]

47. Shorey, M.; Stone, M.C.; Mandel, J.; Rolls, M.M. Neurons survive simultaneous injury to axons and dendrites and regrow both types of processes in vivo. Dev. Biol. 2020, 465, 108-118. [CrossRef]

48. Zhu, P.P.; Soderblom, C.; Tao-Cheng, J.H.; Stadler, J.; Blackstone, C. SPG3A protein atlastin-1 is enriched in growth cones and promotes axon elongation during neuronal development. Hum. Mol. Genet. 2006, 15, 1343-1353. [CrossRef]

49. Nozumi, M.; Togano, T.; Takahashi-Niki, K.; Lu, J.; Honda, A.; Taoka, M.; Shinkawa, T.; Koga, H.; Takeuchi, K.; Isobe, T.; et al. Identification of functional marker proteins in the mammalian growth cone. Proc. Natl. Acad. Sci. USA 2009, 106, 17211-17216. [CrossRef] [PubMed]

50. Saita, S.; Shirane, M.; Natume, T.; Iemura, S.; Nakayama, K.I. Promotion of Neurite Extension by Protrudin Requires Its Interaction with Vesicle-associated Membrane Protein-associated Protein. J. Biol. Chem. 2009, 284, 13766-13777. [CrossRef]

51. De Vincentiis, S.; Falconieri, A.; Mainardi, M.; Cappello, V.; Scribano, V.; Bizzarri, R.; Storti, B.; Dente, L.; Costa, M.; Raffa, V. Extremely Low Forces Induce Extreme Axon Growth. J. Neurosci. 2020, 40, 4997-5007. [CrossRef] [PubMed]

52. Vance, J.E. Newly made phosphatidylserine and phosphatidylethanolamine are preferentially translocated between rat liver mitochondria and endoplasmic reticulum. J. Biol. Chem. 1991, 266, 89-97. [CrossRef]

53. Vance, J.E.; Pan, D.; Campenot, R.B.; Bussiere, M.; Vance, D.E. Evidence that the Major Membrane Lipids, Except Cholesterol, Are Made in Axons of Cultured Rat Sympathetic Neurons. J. Neurochem. 2008, 62, 329-337. [CrossRef] [PubMed]

54. De Chaves, E.P.; Vance, D.E.; Campenot, R.B.; Vance, J.E. Axonal synthesis of phosphatidylcholine is required for normal axonal growth in rat sympathetic neurons. J. Cell Biol. 1995, 128, 913-918. [CrossRef] [PubMed]

55. Luarte, A.; Cornejo, V.H.; Bertin, F.; Gallardo, J.; Couve, A. The axonal endoplasmic reticulum: One organelle-many functions in development, maintenance, and plasticity. Dev. Neurobiol. 2018, 78, 181-208. [CrossRef] [PubMed]

56. Jacquemyn, J.; Cascalho, A.; Goodchild, R.E. The ins and outs of endoplasmic reticulum-controlled lipid biosynthesis. EMBO Rep. 2017, 18, 1905-1921. [CrossRef] [PubMed]

57. Rodríguez-Berdini, L.; Orlando Ferrero, G.; Bustos Plonka, F.; Mauricio Cardozo Gizzi, A.; Prucca, C.G.; Quiroga, S.; Leonor Caputto, B.; Orio, O.A. The moonlighting protein c-Fos activates lipid synthesis in neurons, an activity that is critical for cellular differentiation and cortical development. J. Biol. Chem. 2020, 295, 8808-8818. [CrossRef] 
58. Bakan, I.; Laplante, M. Connecting mTORC1 signaling to SREBP-1 activation. Curr. Opin. Lipidol. 2012, 23, 226-234. [CrossRef]

59. Ricoult, S.J.H.; Yecies, J.L.; Ben-Sahra, I.; Manning, B.D. Oncogenic PI3K and K-Ras stimulate de novo lipid synthesis through mTORC1 and SREBP. Oncogene 2016, 35, 1250-1260. [CrossRef]

60. Ricoult, S.J.H.; Manning, B.D. The multifaceted role of mTORC1 in the control of lipid metabolism. EMBO Rep. 2013, 14, $242-251$. [CrossRef]

61. Lev, S. Nonvesicular lipid transfer from the endoplasmic reticulum. Cold Spring Harb. Perspect. Biol. 2012, 4, a013300. [CrossRef]

62. Lev, S. Non-vesicular lipid transport by lipid-transfer proteins and beyond. Nat. Rev. Mol. Cell Biol. 2010, 11, 739-750. [CrossRef]

63. Wojnacki, J.; Galli, T. Membrane traffic during axon development. Dev. Neurobiol. 2016, 76, 1185-1200. [CrossRef] [PubMed]

64. Kaplan, M.R.; Simoni, R.D. Intracellular transport of phosphatidylcholine to the plasma membrane. J. Cell Biol. 1985, 101, 441-445. [CrossRef] [PubMed]

65. Petkovic, M.; Jemaiel, A.; Daste, F.; Specht, C.G.; Izeddin, I.; Vorkel, D.; Verbavatz, J.-M.; Darzacq, X.; Triller, A.; Pfenninger, K.H.; et al. The SNARE Sec22b has a non-fusogenic function in plasma membrane expansion. Nat. Cell Biol. 2014, 16, 434-444. [CrossRef] [PubMed]

66. Gallo, A.; Vannier, C.; Galli, T. Endoplasmic Reticulum-Plasma Membrane Associations:Structures and Functions. Annu. Rev. Cell Dev. Biol. 2016, 32, 279-301. [CrossRef] [PubMed]

67. Gallo, A.; Danglot, L.; Giordano, F.; Hewlett, B.; Binz, T.; Vannier, C.; Galli, T. Role of the Sec22b-E-Syt complex in neurite growth and ramification. J. Cell Sci. 2020, 133, jcs247148. [CrossRef] [PubMed]

68. Blackmore, M.; Letourneau, P.C. Protein synthesis in distal axons is not required for axon growth in the embryonic spinal cord. Dev. Neurobiol. 2007, 67, 976-986. [CrossRef] [PubMed]

69. Twiss, J.L.; Fainzilber, M. Ribosomes in axons-scrounging from the neighbors? Trends Cell Biol. 2009, 19, 236-243. [CrossRef]

70. Tuck, E.; Cavalli, V. Roles of membrane trafficking in nerve repair and regeneration. Commun. Integr. Biol. 2010, 3, 209-214. [CrossRef]

71. Gumy, L.F.; Tan, C.L.; Fawcett, J.W. The role of local protein synthesis and degradation in axon regeneration. Exp. Neurol. 2010, 223, 28-37. [CrossRef] [PubMed]

72. Willis, D.; Ka, W.L.; Zheng, J.Q.; Chang, J.H.; Smit, A.; Kelly, T.; Merianda, T.T.; Sylvester, J.; Van Minnen, J.; Twiss, J.L. Differential transport and local translation of cytoskeletal, injury-response, and neurodegeneration protein mRNAs in axons. J. Neurosci. 2005, 25, 778-791. [CrossRef] [PubMed]

73. Kalinski, A.L.; Sachdeva, R.; Gomes, C.; Lee, S.J.; Shah, Z.; Houle, J.D.; Twiss, J.L. mRNAs and protein synthetic machinery localize into regenerating spinal cord axons when they are provided a substrate that supports growth. J. Neurosci. 2015, 35, 10357-10370. [CrossRef] [PubMed]

74. Verma, P.; Chierzi, S.; Codd, A.M.; Campbell, D.S.; Meyer, R.L.; Holt, C.E.; Fawcett, J.W. Axonal Protein Synthesis and Degradation Are Necessary for Efficient Growth Cone Regeneration. J. Neurosci. 2005, 25, 331-342. [CrossRef] [PubMed]

75. Merianda, T.T.; Lin, A.C.; Lam, J.S.Y.; Vuppalanchi, D.; Willis, D.E.; Karin, N.; Holt, C.E.; Twiss, J.L. A functional equivalent of endoplasmic reticulum and Golgi in axons for secretion of locally synthesized proteins. Mol. Cell. Neurosci. 2009, 40, 128-142. [CrossRef]

76. Van Erp, S.; van Berkel, A.A.; Feenstra, E.M.; Sahoo, P.K.; Wagstaff, L.; Twiss, J.L.; Fawcett, J.W.; Eva, R.; Ffrench-Constant, C. Age-related loss of axonal regeneration is reflected by the level of local translation. Exp. Neurol. 2021, 113594. [CrossRef]

77. Holt, C.E.; Martin, K.C.; Schuman, E.M. Local translation in neurons: Visualization and function. Nat. Struct. Mol. Biol. 2019, 26, 557-566. [CrossRef]

78. Vuppalanchi, D.; Merianda, T.T.; Donnelly, C.; Pacheco, A.; Williams, G.; Yoo, S.; Ratan, R.R.; Willis, D.E.; Twiss, J.L. Lysophosphatidic acid differentially regulates axonal mRNA translation through 5'UTR elements. Mol. Cell. Neurosci. 2012, 50, 136-146. [CrossRef]

79. Ying, Z.; Misra, V.; Verge, V.M.K. Sensing nerve injury at the axonal ER: Activated Luman/CREB3 serves as a novel axonally synthesized retrograde regeneration signal. Proc. Natl. Acad. Sci. USA 2014, 111, 16142-16147. [CrossRef]

80. Friedman, J.R.; Voeltz, G.K. The ER in 3D: A multifunctional dynamic membrane network. Trends Cell Biol. 2011, $21,709-717$. [CrossRef]

81. De Gregorio, C.; Delgado, R.; Ibacache, A.; Sierralta, J.; Couve, A. Drosophila Atlastin in motor neurons is required for locomotion and presynaptic function. J. Cell Sci. 2017, 130, 3507-3516. [CrossRef]

82. Liu, Y.; Vidensky, S.; Ruggiero, A.M.; Maier, S.; Sitte, H.H.; Rothstein, J.D. Reticulon RTN2B regulates trafficking and function of neuronal glutamate transporter EAAC1. J. Biol. Chem. 2008, 283, 6561-6571. [CrossRef] [PubMed]

83. Kamemura, K.; Chihara, T. Multiple functions of the ER-resident VAP and its extracellular role in neural development and disease. J. Biochem. 2019, 165, 391-400. [CrossRef]

84. Esk, C.; Lindenhofer, D.; Haendeler, S.; Wester, R.A.; Pflug, F.; Schroeder, B.; Bagley, J.A.; Elling, U.; Zuber, J.; von Haeseler, A.; et al. A human tissue screen identifies a regulator of ER secretion as a brain size determinant. Science 2020, 370, eabb5390. [CrossRef]

85. Cui-Wang, T.; Hanus, C.; Cui, T.; Helton, T.; Bourne, J.; Watson, D.; Harris, K.M.; Ehlers, M.D. Local zones of endoplasmic reticulum complexity confine cargo in neuronal dendrites. Cell 2012, 148, 309-321. [CrossRef] 
86. Valenzuela, J.I.; Jaureguiberry-Bravo, M.; Salas, D.A.; Ramírez, O.A.; Cornejo, V.H.; Lu, H.E.; Blanpied, T.A.; Couve, A. Transport along the dendritic endoplasmic reticulum mediates the trafficking of GABAB receptors. J. Cell Sci. 2014, 127, $3382-3395$. [CrossRef] [PubMed]

87. Bowen, A.B.; Bourke, A.M.; Hiester, B.G.; Hanus, C.; Kennedy, M.J. Golgi-Independent secretory trafficking through recycling endosomes in neuronal dendrites and spines. Elife 2017, 6, e27362. [CrossRef]

88. Tojima, T.; Akiyama, H.; Itofusa, R.; Li, Y.; Katayama, H.; Miyawaki, A.; Kamiguchi, H. Attractive axon guidance involves asymmetric membrane transport and exocytosis in the growth cone. Nat. Neurosci. 2007, 10, 58-66. [CrossRef] [PubMed]

89. Tojima, T.; Hines, J.H.; Henley, J.R.; Kamiguchi, H. Second messengers and membrane trafficking direct and organize growth cone steering. Nat. Rev. Neurosci. 2011, 12, 191-203. [CrossRef]

90. Wada, F.; Nakata, A.; Tatsu, Y.; Ooashi, N.; Fukuda, T.; Nabetani, T.; Kamiguchi, H. Myosin Va and Endoplasmic Reticulum Calcium Channel Complex Regulates Membrane Export during Axon Guidance. CellReports 2016, 15, 1329-1344. [CrossRef]

91. Pavez, M.; Thompson, A.C.; Arnott, H.J.; Mitchell, C.B.; D’Atri, I.; Don, E.K.; Chilton, J.K.; Scott, E.K.; Lin, J.Y.; Young, K.M.; et al. STIM1 is required for remodeling of the endoplasmic reticulum and microtubule cytoskeleton in steering growth cones. $J$. Neurosci. 2019, 39, 5095-5114. [CrossRef] [PubMed]

92. Kang, F.; Zhou, M.; Huang, X.; Fan, J.; Wei, L.; Boulanger, J.; Liu, Z.; Salamero, J.; Liu, Y.; Chen, L. E-syt1 Re-arranges STIM1 Clusters to Stabilize Ring-shaped ER-PM Contact Sites and Accelerate Ca 2+ Store Replenishment. Sci. Rep. $2019,9,1-11$.

93. Zaman, M.F.; Nenadic, A.; Radojičić, A.; Rosado, A.; Beh, C.T. Sticking With It: ER-PM Membrane Contact Sites as a Coordinating Nexus for Regulating Lipids and Proteins at the Cell Cortex. Front. Cell Dev. Biol. 2020, 8, 675. [CrossRef]

94. Cho, Y.; Sloutsky, R.; Naegle, K.M.; Cavalli, V. XInjury-Induced HDAC5 nuclear export is essential for axon regeneration. Cell 2013, 155, 894. [CrossRef] [PubMed]

95. Ohtake, Y.; Matsuhisa, K.; Kaneko, M.; Kanemoto, S.; Asada, R.; Imaizumi, K.; Saito, A. Axonal Activation of the Unfolded Protein Response Promotes Axonal Regeneration Following Peripheral Nerve Injury. Neuroscience 2018, 375, 34-48. [CrossRef] [PubMed]

96. Oñate, M.; Catenaccio, A.; Martínez, G.; Armentano, D.; Parsons, G.; Kerr, B.; Hetz, C.; Court, F.A. Activation of the unfolded protein response promotes axonal regeneration after peripheral nerve injury. Sci. Rep. 2016, 6, 1-14. [CrossRef]

97. Valenzuela, V.; Collyer, E.; Armentano, D.; Parsons, G.B.; Court, F.A.; Hetz, C. Activation of the unfolded protein response enhances motor recovery after spinal cord injury. Cell Death Dis. 2012, 3, 272. [CrossRef]

98. Hu, Y.; Park, K.K.; Yang, L.; Wei, X.; Yang, Q.; Cho, K.S.; Thielen, P.; Lee, A.H.; Cartoni, R.; Glimcher, L.H.; et al. Differential effects of unfolded protein response pathways on axon injury-induced death of retinal ganglion cells. Neuron 2012, 73, 445-452. [CrossRef]

99. Halliday, M.; Mallucci, G.R. Review: Modulating the unfolded protein response to prevent neurodegeneration and enhance memory Modulating the unfolded protein response to prevent neurodegeneration and enhance memory. Neuropathol. Appl. Neurobiol. 2015, 41, 414-427. [CrossRef]

100. Hetz, C.; Mollereau, B. Disturbance of endoplasmic reticulum proteostasis in neurodegenerative diseases. Nat. Rev. Neurosci. 2014, 15, 233-249. [CrossRef]

101. De Juan-Sanz, J.; Holt, G.T.; Schreiter, E.R.; de Juan, F.; Kim, D.S.; Ryan, T.A. Axonal Endoplasmic Reticulum Ca2+ Content Controls Release Probability in CNS Nerve Terminals. Neuron 2017, 93, 867-881.e6. [CrossRef]

102. Lindhout, F.W.; Cao, Y.; Kevenaar, J.T.; Bodzęta, A.; Stucchi, R.; Boumpoutsari, M.M.; Katrukha, E.A.; Altelaar, M.; MacGillavry, H.D.; Hoogenraad, C.C. VAP-SCRN1 interaction regulates dynamic endoplasmic reticulum remodeling and presynaptic function. EMBO J. 2019, 38, e101345. [CrossRef]

103. Kuijpers, M.; Kochlamazashvili, G.; Stumpf, A.; Puchkov, D.; Swaminathan, A.; Lucht, M.T.; Krause, E.; Maritzen, T.; Schmitz, D.; Haucke, V. Neuronal Autophagy Regulates Presynaptic Neurotransmission by Controlling the Axonal Endoplasmic Reticulum. Neuron 2020, 109, 299-313.e9. [CrossRef] [PubMed]

104. Ferri, K.F.; Kroemer, G. Organelle-specific initiation of cell death pathways. Nat. Cell Biol. 2001, 3, E255-E263. [CrossRef]

105. Rizzuto, R.; Pozzan, T. Microdomains of intracellular Ca2+: Molecular determinants and functional consequences. Physiol. Rev. 2006, 86, 369-408. [CrossRef] [PubMed]

106. Bock, F.J.; Tait, S.W.G. Mitochondria as multifaceted regulators of cell death. Nat. Rev. Mol. Cell Biol. 2020, 21, 85-100. [CrossRef]

107. Lewis, T.L.; Turi, G.F.; Kwon, S.-K.; Losonczy, A.; Polleux, F. Progressive Decrease of Mitochondrial Motility during Maturation of Cortical Axons In Vitro and In Vivo. Curr. Biol. 2016, 26, 2602-2608. [CrossRef]

108. Smit-Rigter, L.; Rajendran, R.; Silva, C.A.; Spierenburg, L.; Groeneweg, F.; Ruimschotel, E.M.; van Versendaal, D.; van der Togt, C.; Eysel, U.T.; Alexander Heimel, J.; et al. Mitochondrial Dynamics in Visual Cortex Are Limited In Vivo and Not Affected by Axonal Structural Plasticity. Curr. Biol. 2016, 26, 2609-2616. [CrossRef]

109. Mar, F.M.; Simões, A.R.; Leite, S.; Morgado, M.M.; Santos, T.E.; Rodrigo, I.S.; Teixeira, C.A.; Misgeld, T.; Sousa, M.M. CNS axons globally increase axonal transport after peripheral conditioning. J. Neurosci. 2014, 34, 5965-5970. [CrossRef]

110. Misgeld, T.; Kerschensteiner, M.; Bareyre, F.M.; Burgess, R.W.; Lichtman, J.W. Imaging axonal transport of mitochondria in vivo. Nat. Methods 2007, 4, 559-561. [CrossRef]

111. O'Donnell, K.C.; Vargas, M.E.; Sagasti, A. Wlds and PGC-1 $\alpha$ regulate mitochondrial transport and oxidation state after axonal injury. J. Neurosci. 2013, 33, 14778-14790. [CrossRef]

112. Han, S.M.; Baig, H.S.; Hammarlund, M. Mitochondria Localize to Injured Axons to Support Regeneration. Neuron 2016, 92, 1308-1323. [CrossRef] 
113. Hirokawa, N.; Noda, Y.; Tanaka, Y.; Niwa, S. Kinesin superfamily motor proteins and intracellular transport. Nat. Rev. Mol. Cell Biol. 2009, 10, 682-696. [CrossRef] [PubMed]

114. Saxton, W.M.; Hollenbeck, P.J. The axonal transport of mitochondria. J. Cell Sci. 2012, 125, 2095-2104. [CrossRef] [PubMed]

115. Lin, M.Y.; Sheng, Z.H. Regulation of mitochondrial transport in neurons. Exp. Cell Res. 2015, 334, 35-44. [CrossRef]

116. Schwarz, T.L. Mitochondrial trafficking in neurons. Cold Spring Harb. Perspect. Biol. 2013, 5, a011304. [CrossRef]

117. Chang, D.T.W.; Reynolds, I.J. Differences in mitochondrial movement and morphology in young and mature primary cortical neurons in culture. Neuroscience 2006, 141, 727-736. [CrossRef] [PubMed]

118. Zhou, B.; Yu, P.; Lin, M.-Y.; Sun, T.; Chen, Y.; Sheng, Z.-H. Facilitation of axon regeneration by enhancing mitochondrial transport and rescuing energy deficits. J. Cell Biol. 2016, 214, 103-119. [CrossRef]

119. Kang, J.-S.; Tian, J.-H.; Pan, P.-Y.; Zald, P.; Li, C.; Deng, C.; Sheng, Z.-H. Docking of Axonal Mitochondria by Syntaphilin Controls Their Mobility and Affects Short-Term Facilitation. Cell 2008, 132, 137-148. [CrossRef]

120. Sun, T.; Qiao, H.; Pan, P.Y.; Chen, Y.; Sheng, Z.H. Motile axonal mitochondria contribute to the variability of presynaptic strength. Cell Rep. 2013, 4, 413-419. [CrossRef]

121. Steketee, M.B.; Moysidis, S.N.; Weinstein, J.E.; Kreymerman, A.; Silva, J.P.; Iqbal, S.; Goldberg, J.L. Mitochondrial dynamics regulate growth cone motility, guidance, and neurite growth rate in perinatal retinal ganglion cells in vitro. Investig. Ophthalmol. Vis. Sci. 2012, 53, 7402-7411. [CrossRef] [PubMed]

122. Kreymerman, A.; Buickians, D.N.; Nahmou, M.M.; Tran, T.; Galvao, J.; Wang, Y.; Sun, N.; Bazik, L.; Huynh, S.K.; Cho, I.J.; et al MTP18 is a Novel Regulator of Mitochondrial Fission in CNS Neuron Development, Axonal Growth, and Injury Responses. Sci. Rep. 2019, 9, 1-13. [CrossRef]

123. Chen, H.; Detmer, S.A.; Ewald, A.J.; Griffin, E.E.; Fraser, S.E.; Chan, D.C. Mitofusins Mfn1 and Mfn2 coordinately regulate mitochondrial fusion and are essential for embryonic development. J. Cell Biol. 2003, 160, 189-200. [CrossRef]

124. Davies, V.J.; Hollins, A.J.; Piechota, M.J.; Yip, W.; Davies, J.R.; White, K.E.; Nicols, P.P.; Boulton, M.E.; Votruba, M. Opa1 deficiency in a mouse model of autosomal dominant optic atrophy impairs mitochondrial morphology, optic nerve structure and visual function. Hum. Mol. Genet. 2007, 16, 1307-1318. [CrossRef] [PubMed]

125. Lewis, T.L.; Kwon, S.K.; Lee, A.; Shaw, R.; Polleux, F. MFF-dependent mitochondrial fission regulates presynaptic release and axon branching by limiting axonal mitochondria size. Nat. Commun. 2018, 9, 1-15. [CrossRef] [PubMed]

126. Kiryu-Seo, S.; Tamada, H.; Kato, Y.; Yasuda, K.; Ishihara, N.; Nomura, M.; Mihara, K.; Kiyama, H. Mitochondrial fission is an acute and adaptive response in injured motor neurons. Sci. Rep. 2016, 6, 1-14. [CrossRef] [PubMed]

127. Mattson, M.P.; Partin, J. Evidence for mitochondrial control of neuronal polarity. J. Neurosci. Res. 1999, 56, 8-20. [CrossRef]

128. Vaarmann, A.; Mandel, M.; Zeb, A.; Wareski, P.; Liiv, J.; Kuum, M.; Antsov, E.; Liiv, M.; Cagalinec, M.; Choubey, V.; et al. Mitochondrial biogenesis is required for axonal growth. Development 2016, 143, 1981-1992. [CrossRef]

129. Van Spronsen, M.; Mikhaylova, M.; Lipka, J.; Schlager, M.A.; van den Heuvel, D.J.; Kuijpers, M.; Wulf, P.S.; Keijzer, N.; Demmers, J.; Kapitein, L.C.; et al. TRAK/Milton Motor-Adaptor Proteins Steer Mitochondrial Trafficking to Axons and Dendrites. Neuron 2013, 77, 485-502. [CrossRef]

130. Kalinski, A.L.; Kar, A.N.; Craver, J.; Tosolini, A.P.; Sleigh, J.N.; Lee, S.J.; Hawthorne, A.; Brito-Vargas, P.; Miller-Randolph, S.; Passino, R.; et al. Deacetylation of Miro1 by HDAC6 blocks mitochondrial transport and mediates axon growth inhibition. J. Cell Biol. 2019, 218, 1871-1890. [CrossRef]

131. Cavallucci, V.; Bisicchia, E.; Cencioni, M.T.; Ferri, A.; Latini, L.; Nobili, A.; Biamonte, F.; Nazio, F.; Fanelli, F.; Moreno, S.; et al. Acute focal brain damage alters mitochondrial dynamics and autophagy in axotomized neurons. Cell Death Dis. 2014, 5, e1545. [CrossRef]

132. Sheng, Z.H. The Interplay of Axonal Energy Homeostasis and Mitochondrial Trafficking and Anchoring. Trends Cell Biol. 2017, 27, 403-416. [CrossRef] [PubMed]

133. Cartoni, R.; Norsworthy, M.W.; Bei, F.; Wang, C.; Li, S.; Zhang, Y.; Gabel, C.V.; Schwarz, T.L.; He, Z. The Mammalian-Specific Protein Armcx1 Regulates Mitochondrial Transport during Axon Regeneration. Neuron 2016, 92, 1294-1307. [CrossRef] [PubMed]

134. Han, Q.; Xie, Y.; Ordaz, J.D.; Huh, A.J.; Huang, N.; Wu, W.; Liu, N.; Chamberlain, K.A.; Sheng, Z.H.; Xu, X.M. Restoring Cellular Energetics Promotes Axonal Regeneration and Functional Recovery after Spinal Cord Injury. Cell Metab. 2020, 31, 623-641.e8. [CrossRef] [PubMed]

135. Knowlton, W.M.; Hubert, T.; Wu, Z.; Chisholm, A.D.; Jin, Y. A select subset of electron transport chain genes associated with optic atrophy link mitochondria to axon regeneration in Caenorhabditis elegans. Front. Neurosci. 2017, 11, 263. [CrossRef] [PubMed]

136. Rawson, R.L.; Yam, L.; Weimer, R.M.; Bend, E.G.; Hartwieg, E.; Horvitz, H.R.; Clark, S.G.; Jorgensen, E.M. Axons degenerate in the absence of mitochondria in C. elegans. Curr. Biol. 2014, 24, 760-765. [CrossRef] [PubMed]

137. Tang, N.H.; Kim, K.W.; Xu, S.; Blazie, S.M.; Yee, B.A.; Yeo, G.W.; Jin, Y.; Chisholm, A.D. The mRNA Decay Factor CAR-1/LSM14 Regulates Axon Regeneration via Mitochondrial Calcium Dynamics. Curr. Biol. 2020, 30, 865-876.e7. [CrossRef]

138. Chen, Y.; Sheng, Z.H. Kinesin-1-syntaphilin coupling mediates activity-dependent regulation of axonal mitochondrial transport. J. Cell Biol. 2013, 202, 351-364. [CrossRef]

139. Wang, X.; Schwarz, T.L. The Mechanism of Ca2+-Dependent Regulation of Kinesin-Mediated Mitochondrial Motility. Cell 2009, 136, 163-174. [CrossRef]

140. Courchet, J.; Lewis, T.L.; Lee, S.; Courchet, V.; Liou, D.Y.; Aizawa, S.; Polleux, F. Terminal axon branching is regulated by the LKB1-NUAK1 kinase pathway via presynaptic mitochondrial capture. Cell 2013, 153, 1510. [CrossRef] 
141. Tao, K.; Matsuki, N.; Koyama, R. AMP-activated protein kinase mediates activity-dependent axon branching by recruiting mitochondria to axon. Dev. Neurobiol. 2014, 74, 557-573. [CrossRef] [PubMed]

142. Mehta, S.T.; Luo, X.; Park, K.K.; Bixby, J.L.; Lemmon, V.P. Hyperactivated Stat3 boosts axon regeneration in the CNS. Exp. Neurol. 2016, 280, 115-120. [CrossRef]

143. Luo, X.; Ribeiro, M.; Bray, E.R.; Lee, D.H.; Yungher, B.J.; Mehta, S.T.; Thakor, K.A.; Diaz, F.; Lee, J.K.; Moraes, C.T.; et al. Enhanced Transcriptional Activity and Mitochondrial Localization of STAT3 Co-induce Axon Regrowth in the Adult Central Nervous System. Cell Rep. 2016, 15, 398-410. [CrossRef] [PubMed]

144. Fang, Y.; Soares, L.; Teng, X.; Geary, M.; Bonini, N.M. A novel Drosophila model of nerve injury reveals an essential role of Nmnat in maintaining axonal integrity. Curr. Biol. 2012, 22, 590-595. [CrossRef]

145. Perry, V.H.; Brown, M.C.; Lunn, E.R.; Tree, P.; Gordon, S. Evidence that Very Slow Wallerian Degeneration in C57BL/Ola Mice is an Intrinsic Property of the Peripheral Nerve. Eur. J. Neurosci. 1990, 2, 802-808. [CrossRef] [PubMed]

146. Avery, M.A.; Rooney, T.M.; Pandya, J.D.; Wishart, T.M.; Gillingwater, T.H.; Geddes, J.W.; Sullivan, P.G.; Freeman, M.R. Wld S prevents axon degeneration through increased mitochondrial flux and enhanced mitochondrial Ca 2+ buffering. Curr. Biol. 2012, 22, 596-600. [CrossRef] [PubMed]

147. Yap, C.C.; Winckler, B. Harnessing the Power of the Endosome to Regulate Neural Development. Neuron $2012,74,440-451$. [CrossRef] [PubMed]

148. Hausott, B.; Klimaschewski, L. Membrane turnover and receptor trafficking in regenerating axons. Eur. J. Neurosci. 2016, 43, 309-317. [CrossRef]

149. Tojima, T.; Kamiguchi, H. Exocytic and endocytic membrane trafficking in axon development. Dev. Growth Differ. 2015, 57, 291-304. [CrossRef]

150. Villarroel-Campos, D.; Bronfman, F.C.; Gonzalez-Billault, C. Rab GTPase signaling in neurite outgrowth and axon specification. Cytoskeleton 2016, 73, 498-507. [CrossRef]

151. Donaldson, J.G.; Johnson, D.L.; Dutta, D. Rab and Arf G proteins in endosomal trafficking and cell surface homeostasis. Small GTPases 2016, 7, 247-251. [CrossRef]

152. Raiborg, C.; Stenmark, H. The ESCRT machinery in endosomal sorting of ubiquitylated membrane proteins. Nature 2009, 458, 445-452. [CrossRef] [PubMed]

153. Stenmark, H. Rab GTPases as coordinators of vesicle traffic. Nat. Rev. Mol. Cell Biol. 2009, 10, 513-525. [CrossRef] [PubMed]

154. Welz, T.; Wellbourne-Wood, J.; Kerkhoff, E. Orchestration of cell surface proteins by Rab11. Trends Cell Biol. 2014, 24, 407-415. [CrossRef]

155. Van Bergeijk, P.; Adrian, M.; Hoogenraad, C.C.; Kapitein, L.C. Optogenetic control of organelle transport and positioning. Nature 2015, 518, 111-114. [CrossRef] [PubMed]

156. Eva, R.; Dassie, E.; Caswell, P.T.; Dick, G.; ffrench-Constant, C.; Norman, J.C.; Fawcett, J.W. Rab11 and Its Effector Rab Coupling Protein Contribute to the Trafficking of 1 Integrins during Axon Growth in Adult Dorsal Root Ganglion Neurons and PC12 Cells. J. Neurosci. 2010, 30, 11654-11669. [CrossRef] [PubMed]

157. Shirane, M.; Nakayama, K.I. Protrudin Induces Neurite Formation by Directional Membrane Trafficking. Science 2006, 314, 818-821. [CrossRef] [PubMed]

158. Fujita, A.; Koinuma, S.; Yasuda, S.; Nagai, H.; Kamiguchi, H.; Wada, N.; Nakamura, T. GTP hydrolysis of TC10 promotes neurite outgrowth through exocytic fusion of Rab11- and L1-containing vesicles by releasing exocyst component Exo70. PLoS ONE 2013, 8, e79689. [CrossRef] [PubMed]

159. Takano, T.; Urushibara, T.; Yoshioka, N.; Saito, T.; Fukuda, M.; Tomomura, M.; Hisanaga, S.I. LMTK1 regulates dendritic formation by regulating movement of Rab11A-positive endosomes. Mol. Biol. Cell 2014, 25, 1755-1768. [CrossRef] [PubMed]

160. Takano, T.; Tomomura, M.; Yoshioka, N.; Tsutsumi, K.; Terasawa, Y.; Saito, T.; Kawano, H.; Kamiguchi, H.; Fukuda, M.; Hisanaga, S.I. LMTK1/AATYK1 is a novel regulator of axonal outgrowth that acts via Rab11 in a Cdk5-dependent manner. J. Neurosci. 2012, 32, 6587-6599. [CrossRef]

161. Hisanaga, S.I.; Wei, R.; Huo, A.; Tomomura, M. LMTK1, a Novel Modulator of Endosomal Trafficking in Neurons. Front. Mol. Neurosci. 2020, 13. [CrossRef]

162. Koseki, H.; Donegá, M.; Lam, B.Y.; Petrova, V.; van Erp, S.; Yeo, G.S.; Kwok, J.C.; ffrench-Constant, C.; Eva, R.; Fawcett, J.W. Selective rab11 transport and the intrinsic regenerative ability of CNS axons. Elife 2017, 6, e26956. [CrossRef]

163. Montagnac, G.; Sibarita, J.B.; Loubéry, S.; Daviet, L.; Romao, M.; Raposo, G.; Chavrier, P. ARF6 Interacts with JIP4 to Control a Motor Switch Mechanism Regulating Endosome Traffic in Cytokinesis. Curr. Biol. 2009, 19, 184-195. [CrossRef]

164. Eva, R.; Crisp, S.; Marland, J.R.K.; Norman, J.C.; Kanamarlapudi, V.; ffrench-Constant, C.; Fawcett, J.W. ARF6 Directs Axon Transport and Traffic of Integrins and Regulates Axon Growth in Adult DRG Neurons. J. Neurosci. 2012, 32, 10352-10364. [CrossRef]

165. Franssen, E.H.P.; Zhao, R.-R.; Koseki, H.; Kanamarlapudi, V.; Hoogenraad, C.C.; Eva, R.; Fawcett, J.W. Exclusion of Integrins from CNS Axons Is Regulated by Arf6 Activation and the AIS. J. Neurosci. 2015, 35, 8359-8375. [CrossRef] [PubMed]

166. Eva, R.; Koseki, H.; Kanamarlapudi, V.; Fawcett, J.W. EFA6 regulates selective polarised transport and axon regeneration from the axon initial segment. J. Cell Sci. 2017, 130, 3663-3675. [CrossRef] [PubMed]

167. Quiroga, S.; Bisbal, M.; Cáceres, A. Regulation of plasma membrane expansion during axon formation. Dev. Neurobiol. 2018, 78, 170-180. [CrossRef] [PubMed] 
168. Winckler, B.; Yap, C.C. Endocytosis and Endosomes at the Crossroads of Regulating Trafficking of Axon Outgrowth-Modifying Receptors. Traffic 2011, 12, 1099-1108. [CrossRef]

169. Rozés-Salvador, V.; González-Billault, C.; Conde, C. The Recycling Endosome in Nerve Cell Development: One Rab to Rule Them All? Front. Cell Dev. Biol. 2020, 8, 1479. [CrossRef] [PubMed]

170. Falk, J.; Konopacki, F.A.; Zivraj, K.H.; Holt, C.E. Rab5 and rab4 regulate axon elongation in the Xenopus visual system. J. Neurosci. 2014, 34, 373-391. [CrossRef]

171. Ponomareva, O.Y.; Eliceiri, K.W.; Halloran, M.C. Charcot-Marie-Tooth 2b associated Rab7 mutations cause axon growth and guidance defects during vertebrate sensory neuron development. Neural Dev. 2016, 11, 2. [CrossRef]

172. Nakazawa, H.; Sada, T.; Toriyama, M.; Tago, K.; Sugiura, T.; Fukuda, M.; Inagaki, N. Rab33a mediates anterograde vesicular transport for membrane exocytosis and axon outgrowth. J. Neurosci. 2012, 32, 12712-12725. [CrossRef] [PubMed]

173. Villarroel-Campos, D.; Henríquez, D.R.; Bodaleo, F.J.; Oguchi, M.E.; Bronfman, F.C.; Fukuda, M.; Gonzalez-Billault, C. Rab35 functions in axon elongation are regulated by P53-related protein kinase in a mechanism that involves Rab35 protein degradation and the microtubule-associated protein 1B. J. Neurosci. 2016, 36, 7298-7313. [CrossRef] [PubMed]

174. Deng, C.Y.; Lei, W.L.; Xu, X.H.; Ju, X.C.; Liu, Y.; Luo, Z.G. JIP1 mediates anterograde transport of Rab10 cargos during neuronal polarization. J. Neurosci. 2014, 34, 1710-1723. [CrossRef]

175. Liu, Y.; Xu, X.H.; Chen, Q.; Wang, T.; Deng, C.Y.; Song, B.L.; Du, J.L.; Luo, Z.G. Myosin Vb controls biogenesis of post-Golgi Rab10 carriers during axon development. Nat. Commun. 2013, 4, 2005. [CrossRef]

176. Xu, X.H.; Deng, C.Y.; Liu, Y.; He, M.; Peng, J.; Wang, T.; Yuan, L.; Zheng, Z.S.; Blackshear, P.J.; Luo, Z.G. MARCKS regulates membrane targeting of Rab10 vesicles to promote axon development. Cell Res. 2014, 24, 576-594. [CrossRef] [PubMed]

177. Hervera, A.; De Virgiliis, F.; Palmisano, I.; Zhou, L.; Tantardini, E.; Kong, G.; Hutson, T.; Danzi, M.C.; Perry, R.B.T.; Santos, C.X.C.; et al. Reactive oxygen species regulate axonal regeneration through the release of exosomal NADPH oxidase 2 complexes into injured axons. Nat. Cell Biol. 2018, 20, 307-319. [CrossRef]

178. Sekine, Y.; Lin-Moore, A.; Chenette, D.M.; Wang, X.; Jiang, Z.; Cafferty, W.B.; Hammarlund, M.; Strittmatter, S.M. Functional Genome-wide Screen Identifies Pathways Restricting Central Nervous System Axonal Regeneration. Cell Rep. 2018, 23, 415-428. [CrossRef]

179. Xu, H.; Ren, D. Lysosomal physiology. Annu. Rev. Physiol. 2015, 77, 57-80. [CrossRef]

180. Ferguson, S.M. Axonal transport and maturation of lysosomes. Curr. Opin. Neurobiol. 2018, 51, 45-51. [CrossRef]

181. Inpanathan, S.; Botelho, R.J. The lysosome signaling platform: Adapting with the Times. Front. Cell Dev. Biol. 2019, 7, 113. [CrossRef]

182. Ballabio, A.; Bonifacino, J.S. Lysosomes as dynamic regulators of cell and organismal homeostasis. Nat. Rev. Mol. Cell Biol. 2020, 21, 101-118. [CrossRef] [PubMed]

183. Farías, G.G.; Guardia, C.M.; De Pace, R.; Britt, D.J.; Bonifacino, J.S. BORC/kinesin-1 ensemble drives polarized transport of lysosomes into the axon. Proc. Natl. Acad. Sci. USA 2017, 114, E2955-E2964. [CrossRef] [PubMed]

184. Kenific, C.M.; Wittmann, T.; Debnath, J. Autophagy in adhesion and migration. J. Cell Sci. 2016, 129, 3685-3693. [CrossRef] [PubMed]

185. Stavoe, A.K.H.; Holzbaur, E.L.F. Autophagy in neurons. Annu. Rev. Cell Dev. Biol. 2019, 35, 477-500. [CrossRef]

186. Maday, S.; Holzbaur, E.L.F. Compartment-Specific Regulation of Autophagy in Primary Neurons. J. Neurosci. 2016, 36, 5933-5945. [CrossRef] [PubMed]

187. Maday, S.; Wallace, K.E.; Holzbaur, E.L.F. Autophagosomes initiate distally and mature during transport toward the cell soma in primary neurons. J. Cell Biol. 2012, 196, 407-417. [CrossRef]

188. Maday, S.; Holzbaur, E.L.F. Article Autophagosome Biogenesis in Primary Neurons Follows an Ordered and Spatially Regulated Pathway. Dev. Cell 2014, 30, 71-85. [CrossRef]

189. Stavoe, A.K.H.; Hill, S.E.; Hall, D.H.; Colón-Ramos, D.A. KIF1A/UNC-104 Transports ATG-9 to Regulate Neurodevelopment and Autophagy at Synapses. Dev. Cell 2016, 38, 171-185. [CrossRef]

190. Puri, C.; Vicinanza, M.; Ashkenazi, A.; Gratian, M.J.; Zhang, Q.; Bento, C.F.; Renna, M.; Menzies, F.M.; Rubinsztein, D.C. The RAB11A-Positive Compartment Is a Primary Platform for Autophagosome Assembly Mediated by WIPI2 Recognition of PI3P-RAB11A. Dev. Cell 2018, 45, 114-131.e8. [CrossRef]

191. Shibata, M.; Lu, T.; Furuya, T.; Degterev, A.; Mizushima, N.; Yoshimori, T.; MacDonald, M.; Yankner, B.; Yuan, J. Regulation of intracellular accumulation of mutant huntingtin by beclin 1. J. Biol. Chem. 2006, 281, 14474-14485. [CrossRef]

192. Simonsen, A.; Cumming, R.C.; Brech, A.; Isakson, P.; Schubert, D.R.; Finley, K.D. Promoting basal levels of autophagy in the nervous system enhances longevity and oxidant resistance in adult Drosophila. Autophagy 2008, 4, 176-184. [CrossRef] [PubMed]

193. Lipinski, M.M.; Zheng, B.; Lu, T.; Yan, Z.; Py, B.F.; Ng, A.; Xavier, R.J.; Li, C.; Yankner, B.A.; Scherzer, C.R.; et al. Genome-wide analysis reveals mechanisms modulating autophagy in normal brain aging and in Alzheimer's disease. Proc. Natl. Acad. Sci. USA 2010, 107, 14164-14169. [CrossRef] [PubMed]

194. Chang, J.T.; Kumsta, C.; Hellman, A.B.; Adams, L.M.; Hansen, M. Spatiotemporal regulation of autophagy during Caenorhabditis elegans aging. Elife 2017, 6, e18459. [CrossRef] [PubMed]

195. Glatigny, M.; Moriceau, S.; Rivagorda, M.; Ramos-Brossier, M.; Nascimbeni, A.C.; Lante, F.; Shanley, M.R.; Boudarene, N.; Rousseaud, A.; Friedman, A.K.; et al. Autophagy Is Required for Memory Formation and Reverses Age-Related Memory Decline. Curr. Biol. 2019, 29, 435-448.e8. [CrossRef] [PubMed] 
196. Sakamoto, K.; Ozaki, T.; Ko, Y.C.; Tsai, C.F.; Gong, Y.; Morozumi, M.; Ishikawa, Y.; Uchimura, K.; Nadanaka, S.; Kitagawa, H.; et al. Glycan sulfation patterns define autophagy flux at axon tip via PTPRo-cortactin axis. Nat. Chem. Biol. 2019, 15, 699-709. [CrossRef]

197. Tran, A.P.; Warren, P.M.; Silver, J. Regulation of autophagy by inhibitory CSPG interactions with receptor PTP $\sigma$ and its impact on plasticity and regeneration after spinal cord injury. Exp. Neurol. 2020, 328, 113276. [CrossRef]

198. Galluzzi, L.; Green, D.R. Autophagy-Independent Functions of the Autophagy Machinery. Cell 2019, 177, 1682-1699. [CrossRef]

199. He, M.; Ding, Y.; Chu, C.; Tang, J.; Xiao, Q.; Luo, Z.G. Autophagy induction stabilizes microtubules and promotes axon regeneration after spinal cord injury. Proc. Natl. Acad. Sci. USA 2016, 113, 11324-11329. [CrossRef]

200. Kannan, M.; Bayam, E.; Wagner, C.; Rinaldi, B.; Kretz, P.F.; Tilly, P.; Roos, M.; McGillewie, L.; Bär, S.; Minocha, S.; et al. WD40repeat 47 , a microtubule-associated protein, is essential for brain development and autophagy. Proc. Natl. Acad. Sci. USA 2017, 114, E9308-E9317. [CrossRef]

201. Wang, B.; Iyengar, R.; Li-Harms, X.; Joo, J.H.; Wright, C.; Lavado, A.; Horner, L.; Yang, M.; Guan, J.L.; Frase, S.; et al. The autophagy-inducing kinases, ULK1 and ULK2, regulate axon guidance in the developing mouse forebrain via a noncanonical pathway. Autophagy 2018, 14, 796-811. [CrossRef] [PubMed]

202. Nikoletopoulou, V.; Sidiropoulou, K.; Kallergi, E.; Dalezios, Y.; Tavernarakis, N. Modulation of Autophagy by BDNF Underlies Synaptic Plasticity. Cell Metab. 2017, 26, 230-242.e5. [CrossRef]

203. Ban, B.-K.; Jun, M.-H.; Ryu, H.-H.; Jang, D.-J.; Ahmad, S.T.; Lee, J.-A. Autophagy Negatively Regulates Early Axon Growth in Cortical Neurons. Mol. Cell. Biol. 2013, 33, 3907-3919. [CrossRef] [PubMed]

204. Clarke, J.-P.; Mearow, K. Autophagy inhibition in endogenous and nutrient-deprived conditions reduces dorsal root ganglia neuron survival and neurite growth in vitro. J. Neurosci. Res. 2016, 94, 653-670. [CrossRef]

205. Rabanal-Ruiz, Y.; Korolchuk, V.I. mTORC1 and nutrient homeostasis: The central role of the lysosome. Int. J. Mol. Sci. 2018, 19, 818. [CrossRef] [PubMed]

206. Wei, X.; Luo, L.; Chen, J. Roles of mTOR Signaling in Tissue Regeneration. Cells 2019, 8, 1075. [CrossRef]

207. Kim, J.; Guan, K.L. mTOR as a central hub of nutrient signalling and cell growth. Nat. Cell Biol. 2019, 21, 63-71. [CrossRef] [PubMed]

208. Abe, N.; Borson, S.H.; Gambello, M.J.; Wang, F.; Cavalli, V. Mammalian Target of Rapamycin (mTOR) activation increases axonal growth capacity of injured peripheral nerves. J. Biol. Chem. 2010, 285, 28034-28043. [CrossRef]

209. Danilov, C.A.; Steward, O. Conditional genetic deletion of PTEN after a spinal cord injury enhances regenerative growth of CST axons and motor function recovery in mice. Exp. Neurol. 2015, 266, 147-160. [CrossRef]

210. Geoffroy, C.G.; Hilton, B.J.; Tetzlaff, W.; Zheng, B. Evidence for an Age-Dependent Decline in Axon Regeneration in the Adult Mammalian Central Nervous System. Cell Rep. 2016, 15, 238-246. [CrossRef]

211. Leibinger, M.; Andreadaki, A.; Golla, R.; Levin, E.; Hilla, A.M.; Diekmann, H.; Fischer, D. Boosting CNS axon regeneration by harnessing antagonistic effects of GSK3 activity. Proc. Natl. Acad. Sci. USA 2017, 114, E5454-E5463. [CrossRef]

212. Leibinger, M.; Hilla, A.M.; Andreadaki, A.; Fischer, D. GSK3-CRMP2 signaling mediates axonal regeneration induced by Pten knockout. Commun. Biol. 2019, 2, 318. [CrossRef]

213. Miao, L.; Yang, L.; Huang, H.; Liang, F.; Ling, C.; Hu, Y. MTORC1 is necessary but mTORC2 and GSK3 $\beta$ are inhibitory for AKT3-induced axon regeneration in the central nervous system. Elife 2016, 5, e14908. [CrossRef] [PubMed]

214. Tassew, N.G.; Charish, J.; Shabanzadeh, A.P.; Luga, V.; Harada, H.; Farhani, N.; D'Onofrio, P.; Choi, B.; Ellabban, A.; Nickerson, P.E.B.; et al. Exosomes Mediate Mobilization of Autocrine Wnt10b to Promote Axonal Regeneration in the Injured CNS. Cell Rep. 2017, 20, 99-111. [CrossRef] [PubMed]

215. Pita-Thomas, W.; Mahar, M.; Joshi, A.; Gan, D.; Cavalli, V. HDAC5 promotes optic nerve regeneration by activating the mTOR pathway. Exp. Neurol. 2019, 317, 271-283. [CrossRef] [PubMed]

216. Poulopoulos, A.; Murphy, A.J.; Ozkan, A.; Davis, P.; Hatch, J.; Kirchner, R.; Macklis, J.D. Subcellular transcriptomes and proteomes of developing axon projections in the cerebral cortex. Nature 2019, 565, 356-360. [CrossRef]

217. Rodríguez, A.; Webster, P.; Ortego, J.; Andrews, N.W. Lysosomes behave as Ca2+-regulated exocytic vesicles in fibroblasts and epithelial cells. J. Cell Biol. 1997, 137, 93-104. [CrossRef]

218. Reddy, A.; Caler, E.V.; Andrews, N.W. Plasma membrane repair is mediated by Ca2+-regulated exocytosis of lysosomes. Cell 2001, 106, 157-169. [CrossRef]

219. Jaiswal, J.K.; Andrews, N.W.; Simon, S.M. Membrane proximal lysosomes are the major vesicles responsible for calcium-dependent exocytosis in nonsecretory cells. J. Cell Biol. 2002, 159, 625-635. [CrossRef]

220. Arantes, R.M.E.; Andrews, N.W. A role for synaptotagmin VII-regulated exocytosis of lysosomes in neurite outgrowth from primary sympathetic neurons. J. Neurosci. 2006, 26, 4630-4637. [CrossRef]

221. Czibener, C.; Sherer, N.M.; Becker, S.M.; Pypaert, M.; Hui, E.; Chapman, E.R.; Mothes, W.; Andrews, N.W. Ca2+ and synaptotagmin VII-dependent delivery of lysosomal membrane to nascent phagosomes. J. Cell Biol. 2006, 174, 997-1007. [CrossRef]

222. Sato, M.; Yoshimura, S.; Hirai, R.; Goto, A.; Kunii, M.; Atik, N.; Sato, T.; Sato, K.; Harada, R.; Shimada, J.; et al. The role of VAMP7/TI-VAMP in cell polarity and lysosomal exocytosis in vivo. Traffic 2011, 12, 1383-1393. [CrossRef]

223. Naegeli, K.M.; Hastie, E.; Garde, A.; Wang, Z.; Keeley, D.P.; Gordon, K.L.; Pani, A.M.; Kelley, L.C.; Morrissey, M.A.; Chi, Q.; et al Cell Invasion In Vivo via Rapid Exocytosis of a Transient Lysosome-Derived Membrane Domain. Dev. Cell 2017, 43, 403-417.e10. [CrossRef] 
224. Jiang, M.; Meng, J.; Zeng, F.; Qing, H.; Hook, G.; Hook, V.; Wu, Z.; Ni, J. Cathepsin B inhibition blocks neurite outgrowth in cultured neurons by regulating lysosomal trafficking and remodeling. J. Neurochem. 2020, 155, 300-312. [CrossRef]

225. Jung, J.; Shin, Y.H.; Konishi, H.; Lee, S.J.; Kiyama, H. Possible ATP release through lysosomal exocytosis from primary sensory neurons. Biochem. Biophys. Res. Commun. 2013, 430, 488-493. [CrossRef]

226. Tam, C.; Idone, V.; Devlin, C.; Fernandes, M.C.; Flannery, A.; He, X.; Schuchman, E.; Tabas, I.; Andrews, N.W. Exocytosis of acid sphingomyelinase by wounded cells promotes endocytosis and plasma membrane repair. J. Cell Biol. 2010, 189, 1027-1038. [CrossRef]

227. Castro-Gomes, T.; Corrotte, M.; Tam, C.; Andrews, N.W. Plasma membrane repair is regulated extracellularly by proteases released from lysosomes. PLoS ONE 2016, 11, e0152583.

228. Korhonen, L.; Lindholm, D. The ubiquitin proteasome system in synaptic and axonal degeneration: A new twist to an old cycle. J. Cell Biol. 2004, 165, 27-30. [CrossRef] [PubMed]

229. Lee, M.; Liu, Y.C.; Chen, C.; Lu, C.H.; Lu, S.T.; Huang, T.N.; Hsu, M.T.; Hsueh, Y.P.; Cheng, P.L. Ecm29-mediated proteasomal distribution modulates excitatory GABA responses in the developing brain. J. Cell Biol. 2020, 219, e201903033. [CrossRef] [PubMed]

230. Minis, A.; Rodriguez, J.A.; Levin, A.; Liu, K.; Govek, E.E.; Hatten, M.E.; Steller, H. The proteasome regulator PI31 is required for protein homeostasis, synapse maintenance, and neuronal survival in mice. Proc. Natl. Acad. Sci. USA 2019, 116, 24639-24650. [CrossRef] [PubMed]

231. Otero, M.G.; Alloatti, M.; Cromberg, L.E.; Almenar-Queralt, A.; Encalada, S.E.; Pozo Devoto, V.M.; Bruno, L.; Goldstein, L.S.B.; Falzone, T.L. Fast axonal transport of the proteasome complex depends on membrane interaction and molecular motor function. J. Cell Sci. 2014, 127, 1537-1549. [CrossRef]

232. Bingol, B.; Schuman, E.M. Activity-dependent dynamics and sequestration of proteasomes in dendritic spines. Nature 2006, 441, 1144-1148. [CrossRef]

233. Hamilton, A.M.; Zito, K. Breaking it down: The ubiquitin proteasome system in neuronal morphogenesis. Neural Plast. 2013, 2013, 196848. [CrossRef] [PubMed]

234. DiAntonio, A.; Hicke, L. Ubiquitin-Dependent Regulation of the Synapse. Annu. Rev. Neurosci. 2004, 27, 223-246. [CrossRef] [PubMed]

235. Ohtani-Kaneko, R.; Takada, K.; Iigo, M.; Hara, M.; Yokosawa, H.; Kawashima, S.; Ohkawa, K.; Hirata, K. Proteasome inhibitors which induce neurite outgrowth from PC12h cells cause different subcellular accumulations of multi-ubiquitin chains. Neurochem. Res. 1998, 23, 1435-1443. [CrossRef] [PubMed]

236. Obin, M.; Mesco, E.; Gong, X.; Haas, A.L.; Joseph, J.; Taylor, A. Neurite outgrowth in PC12 cells: Distinguishing the roles of ubiquitylation and ubiquitin-dependent proteolysis. J. Biol. Chem. 1999, 274, 11789-11795. [CrossRef]

237. Ōmura, S.; Fujimoto, T.; Otoguro, K.; Matsuzaki, K.; Moriguchi, R.; Tanaka, H.; Sasaki, Y. Lactacystin, a novel microbial metabolite, induces neurito-genesis of neuroblastoma cells. J. Antibiot. 1991, 44, 113-116. [CrossRef]

238. Klimaschewski, L.; Hausott, B.; Ingorokva, S.; Pfaller, K. Constitutively expressed catalytic proteasomal subunits are up-regulated during neuronal differentiation and required for axon initiation, elongation and maintenance. J. Neurochem. 2006, 96, 1708-1717. [CrossRef]

239. Laser, H.; Mack, T.G.A.; Wagner, D.; Coleman, M.P. Proteasome inhibition arrests neurite outgrowth and causes dying-back degeneration in primary culture. J. Neurosci. Res. 2003, 74, 906-916. [CrossRef]

240. Zheng, Q.; Huang, T.; Zhang, L.; Zhou, Y.; Luo, H.; Xu, H.; Wang, X. Dysregulation of ubiquitin-proteasome system in neurodegenerative diseases. Front. Aging Neurosci. 2016, 8, 303. [CrossRef] [PubMed]

241. Njomen, E.; Tepe, J.J. Proteasome Activation as a New Therapeutic Approach to Target Proteotoxic Disorders. J. Med. Chem. 2019, 62, 6469-6481. [CrossRef]

242. Tanaka, K.; Matsuda, N. Proteostasis and neurodegeneration: The roles of proteasomal degradation and autophagy. Biochim. Biophys. Acta-Mol. Cell Res. 2014, 1843, 197-204. [CrossRef]

243. Jin, E.J.; Ko, H.R.; Hwang, I.; Kim, B.S.; Choi, J.Y.; Park, K.W.; Cho, S.W.; Ahn, J.Y. Akt regulates neurite growth by phosphorylationdependent inhibition of radixin proteasomal degradation. Sci. Rep. 2018, 8, 2557. [CrossRef] [PubMed]

244. Tursun, B.; Schlüter, A.; Peters, M.A.; Viehweger, B.; Ostendorff, H.P.; Soosairajah, J.; Drung, A.; Bossenz, M.; Johnsen, S.A.; Schweizer, M.; et al. The ubiquitin ligase Rnf6 regulates local LIM kinase 1 levels in axonal growth cones. Genes Dev. 2005, 19, 2307-2319. [CrossRef] [PubMed]

245. Yan, D.; Guo, L.; Wang, Y. Requirement of dendritic Akt degradation by the ubiquitin-proteasome system for neuronal polarity. J. Cell Biol. 2006, 174, 415-424. [CrossRef] [PubMed]

246. Takabatake, M.; Goshima, Y.; Sasaki, Y. Semaphorin-3A Promotes Degradation of Fragile X Mental Retardation Protein in Growth Cones via the Ubiquitin-Proteasome Pathway. Front. Neural Circuits 2020, 14, 5. [CrossRef]

247. Campbell, D.S.; Holt, C.E. Chemotropic responses of retinal growth cones mediated by rapid local protein synthesis and degradation. Neuron 2001, 32, 1013-1026. [CrossRef]

248. Hsu, M.-T.; Guo, C.-L.; Liou, A.Y.; Chang, T.-Y.; Ng, M.-C.; Florea, B.I.; Overkleeft, H.S.; Wu, Y.-L.; Liao, J.-C.; Cheng, P.-L. Stage-Dependent Axon Transport of Proteasomes Contributes to Axon Development. Dev. Cell 2015, 35, 418-431. [CrossRef] 
249. Knöferle, J.; Ramljak, S.; Koch, J.C.; Tönges, L.; Asif, A.R.; Michel, U.; Wouters, F.S.; Heermann, S.; Krieglstein, K.; Zerr, I.; et al. TGF- $\beta 1$ enhances neurite outgrowth via regulation of proteasome function and EFABP. Neurobiol. Dis. 2010, 38, 395-404. [CrossRef]

250. Park, J.Y.; Jang, S.Y.; Shin, Y.K.; Suh, D.J.; Park, H.T. Calcium-dependent proteasome activation is required for axonal neurofilament degradation. Neural Regen. Res. 2013, 8, 3401.

251. Staal, J.A.; Dickson, T.C.; Chung, R.S.; Vickers, J.C. Disruption of the Ubiquitin Proteasome System following Axonal Stretch Injury Accelerates Progression to Secondary Axotomy. J. Neurotrauma 2009, 26, 781-788. [CrossRef]

252. Valm, A.M.; Cohen, S.; Legant, W.R.; Melunis, J.; Hershberg, U.; Wait, E.; Cohen, A.R.; Davidson, M.W.; Betzig, E.; LippincottSchwartz, J. Applying systems-level spectral imaging and analysis to reveal the organelle interactome. Nature 2017, 546, 162-167. [CrossRef]

253. Lee, S.; Wang, W.; Hwang, J.; Namgung, U.; Min, K.T. Increased ER-mitochondria tethering promotes axon regeneration. Proc. Natl. Acad. Sci. USA 2019, 116, 16074-16079. [CrossRef] [PubMed]

254. Krauß, M.; Haucke, V. A grab to move on: ER -endosome contacts in membrane protrusion formation and neurite outgrowth EMBO J. 2015, 34, 1442-1444. [CrossRef] [PubMed]

255. Wu, H.; Carvalho, P.; Voeltz, G.K. Here, there, and everywhere: The importance of ER membrane contact sites. Science $2018,361$. [CrossRef]

256. Mannan, A.U.; Krawen, P.; Sauter, S.M.; Boehm, J.; Chronowska, A.; Paulus, W.; Neesen, J.; Engel, W. ZFYVE27 (SPG33), a Novel Spastin-Binding Protein, Is Mutated in Hereditary Spastic Paraplegia. Am. J. Hum. Genet. 2006, 79, 351-357. [CrossRef]

257. Evans, K.; Keller, C.; Pavur, K.; Glasgow, K.; Conn, B.; Lauring, B. Interaction of two hereditary spastic paraplegia gene products, spastin and atlastin, suggests a common pathway for axonal maintenance. Proc. Natl. Acad. Sci. USA 2006, 103, 10666-10671. [CrossRef] [PubMed]

258. Züchner, S.; Wang, G.; Tran-Viet, K.N.; Nance, M.A.; Gaskell, P.C.; Vance, J.M.; Ashley-Koch, A.E.; Pericak-Vance, M.A. Mutations in the novel mitochondrial protein REEP1 cause hereditary spastic paraplegia type 31. Am. J. Hum. Genet. 2006, 79, 365-369. [CrossRef]

259. Beetz, C.; Schüle, R.; Deconinck, T.; Tran-Viet, K.N.; Zhu, H.; Kremer, B.P.H.; Frints, S.G.M.; Van Zelst-Stams, W.A.G.; Byrne, P.; Otto, S.; et al. REEP1 mutation spectrum and genotype/phenotype correlation in hereditary spastic paraplegia type 31 . Brain 2008, 131, 1078-1086. [CrossRef]

260. Nishimura, A.L.; Mitne-Neto, M.; Silva, H.C.A.; Richieri-Costa, A.; Middleton, S.; Cascio, D.; Kok, F.; Oliveira, J.R.M.; Gillingwater, T.; Webb, J.; et al. A mutation in the vesicle-trafficking protein VAPB causes late-onset spinal muscular atrophy and amyotrophic lateral sclerosis. Am. J. Hum. Genet. 2004, 75, 822-831. [CrossRef]

261. Kitada, T.; Asakawa, S.; Hattori, N.; Matsumine, H.; Yamamura, Y.; Minoshima, S.; Yokochi, M.; Mizuno, Y.; Shimizu, N. Mutations in the parkin gene cause autosomal recessive juvenile parkinsonism. Nature 1998, 392, 605-608. [CrossRef] [PubMed]

262. Valente, E.M.; Abou-Sleiman, P.M.; Caputo, V.; Muqit, M.M.K.; Harvey, K.; Gispert, S.; Ali, Z.; Del Turco, D.; Bentivoglio, A.R.; Healy, D.G.; et al. Hereditary early-onset Parkinson's disease caused by mutations in PINK1. Science 2004, 304, 1158-1160. [CrossRef] [PubMed]

263. Valente, E.M.; Salvi, S.; Ialongo, T.; Marongiu, R.; Elia, A.E.; Caputo, V.; Romito, L.; Albanese, A.; Dallapiccola, B.; Bentivoglio, A.R. PINK1 mutations are associated with sporadic early-onset Parkinsonism. Ann. Neurol. 2004, 56, 336-341. [CrossRef] [PubMed]

264. Züchner, S.; Mersiyanova, I.V.; Muglia, M.; Bissar-Tadmouri, N.; Rochelle, J.; Dadali, E.L.; Zappia, M.; Nelis, E.; Patitucci, A.; Senderek, J.; et al. Mutations in the mitochondrial GTPase mitofusin 2 cause Charcot-Marie-Tooth neuropathy type 2A. Nat. Genet. 2004, 36, 449-451. [CrossRef] [PubMed]

265. Sidiropoulos, P.N.M.; Miehe, M.; Bock, T.; Tinelli, E.; Oertli, C.I.; Kuner, R.; Meijer, D.; Wollscheid, B.; Niemann, A.; Suter, U. Dynamin 2 mutations in Charcot-Marie-Tooth neuropathy highlight the importance of clathrin-mediated endocytosis in myelination. Brain 2012, 135, 1395-1411. [CrossRef]

266. Böhm, J.; Bulla, M.; Urquhart, J.E.; Malfatti, E.; Williams, S.G.; O’Sullivan, J.; Szlauer, A.; Koch, C.; Baranello, G.; Mora, M.; et al. ORAI1 Mutations with Distinct Channel Gating Defects in Tubular Aggregate Myopathy. Hum. Mutat. 2017, 38, 426-438. [CrossRef] [PubMed]

267. Xu, L.; Wang, X.; Tong, C. Endoplasmic Reticulum-Mitochondria Contact Sites and Neurodegeneration. Front. Cell Dev. Biol. 2020, 8, 428. [CrossRef]

268. Rieusset, J. The role of endoplasmic reticulum-mitochondria contact sites in the control of glucose homeostasis: An update. Cell Death Dis. 2018, 9, 388. [CrossRef] [PubMed]

269. Rowland, A.A.; Voeltz, G.K. Endoplasmic reticulum-mitochondria contacts: Function of the junction. Nat. Rev. Mol. Cell Biol. 2012, 13, 607-615. [CrossRef]

270. Marchi, S.; Patergnani, S.; Pinton, P. The endoplasmic reticulum-mitochondria connection: One touch, multiple functions. Biochim. Biophys. Acta-Bioenerg. 2014, 1837, 461-469. [CrossRef]

271. Bravo-Sagua, R.; Torrealba, N.; Paredes, F.; Morales, P.E.; Pennanen, C.; López-Crisosto, C.; Troncoso, R.; Criollo, A.; Chiong, M.; Hill, J.A.; et al. Organelle communication: Signaling crossroads between homeostasis and disease. Int. J. Biochem. Cell Biol. 2014, 50, 55-59. [CrossRef]

272. Grimm, S. The ER-mitochondria interface: The social network of cell death. Biochim. Biophys. Acta-Mol. Cell Res. 2012, 1823, 327-334. [CrossRef] [PubMed] 
273. Bernard-Marissal, N.; Médard, J.J.; Azzedine, H.; Chrast, R. Dysfunction in endoplasmic reticulum-mitochondria crosstalk underlies SIGMAR1 loss of function mediated motor neuron degeneration. Brain 2015, 138, 875-890. [CrossRef] [PubMed]

274. Bernard-Marissal, N.; Chrast, R.; Schneider, B.L. Endoplasmic reticulum and mitochondria in diseases of motor and sensory neurons: A broken relationship? Cell Death Dis. 2018, 9, 1-16. [CrossRef]

275. Stoica, R.; De Vos, K.J.; Paillusson, S.; Mueller, S.; Sancho, R.M.; Lau, K.F.; Vizcay-Barrena, G.; Lin, W.L.; Xu, Y.F.; Lewis, J.; et al ER-mitochondria associations are regulated by the VAPB-PTPIP51 interaction and are disrupted by ALS/FTD-associated TDP-43. Nat. Commun. 2014, 5, 399. [CrossRef]

276. Guardia-Laguarta, C.; Area-Gomez, E.; Rüb, C.; Liu, Y.; Magrané, J.; Becker, D.; Voos, W.; Schon, E.A.; Przedborski, S. $\alpha$-synuclein is localized to mitochondria-associated ER membranes. J. Neurosci. 2014, 34, 249-259. [CrossRef]

277. Schon, E.A.; Area-Gomez, E. Mitochondria-associated ER membranes in Alzheimer disease. Mol. Cell. Neurosci. 2013, 55, 26-36. [CrossRef]

278. Calì, T.; Ottolini, D.; Negro, A.; Brini, M. $\alpha$-synuclein controls mitochondrial calcium homeostasis by enhancing endoplasmic reticulum-mitochondria interactions. J. Biol. Chem. 2012, 287, 17914-17929. [CrossRef]

279. Zampese, E.; Fasolato, C.; Kipanyula, M.J.; Bortolozzi, M.; Pozzan, T.; Pizzo, P. Presenilin 2 modulates endoplasmic reticulum (ER)-mitochondria interactions and Ca2+ cross-talk. Proc. Natl. Acad. Sci. USA 2011, 108, 2777-2782. [CrossRef]

280. Szabadkai, G.; Bianchi, K.; Várnai, P.; De Stefani, D.; Wieckowski, M.R.; Cavagna, D.; Nagy, A.I.; Balla, T.; Rizzuto, R. Chaperonemediated coupling of endoplasmic reticulum and mitochondrial Ca2+ channels. J. Cell Biol. 2006, 175, 901-911. [CrossRef] [PubMed]

281. Trigo, D.; Goncalves, M.B.; Corcoran, J.P.T. The regulation of mitochondrial dynamics in neurite outgrowth by retinoic acid receptor $\beta$ signaling. FASEB J. 2019, 33, 7225-7235. [CrossRef]

282. Friedman, J.R.; DiBenedetto, J.R.; West, M.; Rowland, A.A.; Voeltz, G.K. Endoplasmic reticulum-endosome contact increases as endosomes traffic and mature. Mol. Biol. Cell 2013, 24, 1030-1040. [CrossRef] [PubMed]

283. Raiborg, C.; Wenzel, E.M.; Stenmark, H. ER -endosome contact sites: Molecular compositions and functions. EMBO J. 2015, 34, 1848-1858. [CrossRef] [PubMed]

284. Lu, M.; van Tartwijk, F.W.; Lin, J.Q.; Nijenhuis, W.; Parutto, P.; Fantham, M.; Christensen, C.N.; Avezov, E.; Holt, C.E.; Tunnacliffe, A.; et al. The structure and global distribution of the endoplasmic reticulum network are actively regulated by lysosomes. Sci. Adv. 2020, 6, eabc7209. [CrossRef]

285. Raiborg, C.; Wenzel, E.M.; Pedersen, N.M.; Olsvik, H.; Schink, K.O.; Schultz, S.W.; Vietri, M.; Nisi, V.; Bucci, C.; Brech, A.; et al. Repeated ER-endosome contacts promote endosome translocation and neurite outgrowth. Nature 2015, 520, 234-238. [CrossRef] [PubMed]

286. Allison, R.; Lumb, J.H.; Fassier, C.; Connell, J.W.; Martin, D.T.; Seaman, M.N.J.; Hazan, J.; Reid, E. An ESCRT-spastin interaction promotes fission of recycling tubules from the endosome. J. Cell Biol. 2013, 202, 527-543. [CrossRef] [PubMed]

287. Allison, R.; Edgar, J.R.; Pearson, G.; Rizo, T.; Newton, T.; Günther, S.; Berner, F.; Hague, J.; Connell, J.W.; Winkler, J.; et al. Defects in ER-endosome contacts impact lysosome function in hereditary spastic paraplegia. J. Cell Biol. 2017, 216, 1337-1355. [CrossRef] [PubMed]

288. Eden, E.R.; White, I.J.; Tsapara, A.; Futter, C.E. Membrane contacts between endosomes and ER provide sites for PTP1B-epidermal growth factor receptor interaction. Nat. Cell Biol. 2010, 12, 267-272. [CrossRef]

289. Eden, E.R.; Sanchez-Heras, E.; Tsapara, A.; Sobota, A.; Levine, T.P.; Futter, C.E. Annexin A1 Tethers Membrane Contact Sites that Mediate ER to Endosome Cholesterol Transport. Dev. Cell 2016, 37, 473-483. [CrossRef]

290. Kilpatrick, B.S.; Eden, E.R.; Hockey, L.N.; Yates, E.; Futter, C.E.; Patel, S. An Endosomal NAADP-Sensitive Two-Pore Ca2+ Channel Regulates ER-Endosome Membrane Contact Sites to Control Growth Factor Signaling. Cell Rep. 2017, 18, 1636-1645. [CrossRef] [PubMed]

291. Petkovic, M.; Oses-Prieto, J.; Burlingame, A.; Jan, L.Y.; Jan, Y.N. TMEM16K is an interorganelle regulator of endosomal sorting. Nat. Commun. 2020, 11, 1-16. [CrossRef] [PubMed]

292. Elbaz-Alon, Y.; Guo, Y.; Segev, N.; Harel, M.; Quinnell, D.E.; Geiger, T.; Avinoam, O.; Li, D.; Nunnari, J. PDZD8 interacts with Protrudin and Rab7 at ER-late endosome membrane contact sites associated with mitochondria. Nat. Commun. 2020, 11, 1-14. [CrossRef] [PubMed]

293. Hirabayashi, Y.; Kwon, S.K.; Paek, H.; Pernice, W.M.; Paul, M.A.; Lee, J.; Erfani, P.; Raczkowski, A.; Petrey, D.S.; Pon, L.A.; et al. ER-mitochondria tethering by PDZD8 regulates Ca2+ dynamics in mammalian neurons. Science 2017, 358, 623-630. [CrossRef] [PubMed]

294. Liao, Y.C.; Fernandopulle, M.S.; Wang, G.; Choi, H.; Hao, L.; Drerup, C.M.; Patel, R.; Qamar, S.; Nixon-Abell, J.; Shen, Y.; et al. RNA Granules Hitchhike on Lysosomes for Long-Distance Transport, Using Annexin A11 as a Molecular Tether. Cell 2019, 179, 147-164.e20. [CrossRef]

295. Lee, J.E.; Cathey, P.I.; Wu, H.; Parker, R.; Voeltz, G.K. Endoplasmic reticulum contact sites regulate the dynamics of membraneless organelles. Science 2020, 367, eaay7108. [CrossRef] [PubMed]

296. Cai, Q.; Zakaria, H.M.; Simone, A.; Sheng, Z.H. Spatial parkin translocation and degradation of damaged mitochondria via mitophagy in live cortical neurons. Curr. Biol. 2012, 22, 545-552. [CrossRef] [PubMed]

297. Miller, K.E.; Sheetz, M.P. Axonal mitochondrial transport and potential are correlated. J. Cell Sci. 2004, 117, 2791-2804. [CrossRef] 
298. Lin, M.Y.; Cheng, X.T.; Tammineni, P.; Xie, Y.; Zhou, B.; Cai, Q.; Sheng, Z.H. Releasing Syntaphilin Removes Stressed Mitochondria from Axons Independent of Mitophagy under Pathophysiological Conditions. Neuron 2017, 94, 595-610.e6. [CrossRef]

299. Zheng, Y.; Zhang, X.; Wu, X.; Jiang, L.; Ahsan, A.; Ma, S.; Xiao, Z.; Han, F.; Qin, Z.H.; Hu, W.; et al. Somatic autophagy of axonal mitochondria in ischemic neurons. J. Cell Biol. 2019, 218, 1891-1907. [CrossRef]

300. Wang, X.; Winter, D.; Ashrafi, G.; Schlehe, J.; Wong, Y.L.; Selkoe, D.; Rice, S.; Steen, J.; Lavoie, M.J.; Schwarz, T.L. PINK1 and Parkin target miro for phosphorylation and degradation to arrest mitochondrial motility. Cell 2011, 147, 893-906. [CrossRef]

301. Ashrafi, G.; Schlehe, J.S.; LaVoie, M.J.; Schwarz, T.L. Mitophagy of damaged mitochondria occurs locally in distal neuronal axons and requires PINK1 and Parkin. J. Cell Biol. 2014, 206, 655-670. [CrossRef] [PubMed]

302. Gabriela Otero, M.; Fernandez Bessone, I.; Earle Hallberg, A.; Eneas Cromberg, L.; Cecilia De Rossi, M.; Saez, T.M.; Levi, V.; Almenar-Queralt, A.; Luis Falzone, T. Proteasome Stress Leads to APP Axonal Transport Defects by Promoting Its Amyloidogenic Processing in Lysosomes. 2018. Available online: http://jcs.biologists.org/content/joces/early/2018/05/02/jcs.214536.full.pdf (accessed on 6 March 2019). 